\title{
Hydrogenophaga, a New Genus of Hydrogen-Oxidizing Bacteria That Includes Hydrogenophaga flava comb. nov. (Formerly Pseudomonas flava), Hydrogenophaga palleronii (Formerly Pseudomonas palleronii), Hydrogenophaga pseudoflava (Formerly Pseudomonas pseudoflava and "Pseudomonas carboxydoflava'), and Hydrogenophaga taeniospiralis (Formerly Pseudomonas taeniospiralis)
}

\author{
A. WILLEMS,${ }^{1}$ J. BUSSE, ${ }^{2}$ M. GOOR,${ }^{1}$ B. POT, ${ }^{1}$ E. FALSEN,${ }^{3}$ E. JANTZEN,${ }^{4}$ B. HOSTE,${ }^{1}$ M. GILLIS,${ }^{1}$ \\ K. KERSTERS, ${ }^{1}$ G. AULING ${ }^{2}$ AND J. DE LEY ${ }^{1 *}$ \\ Laboratorium voor Microbiologie en Microbiële Genetica, Rijksuniversiteit, B-9000 Ghent, Belgium ${ }^{1}$; Institut für \\ Mikrobiologie, Universität Hannover, D-3000 Hannover, Federal Republic of Germany ${ }^{2}$; Culture Collection, \\ Department of Clinical Bacteriology, University of Göteborg, S-413 46 Göteborg, Sweden ${ }^{3}$; and \\ Department of Methodology, National Institute of Public Health, N-0462 Oslo, Norway ${ }^{4}$
}

\begin{abstract}
The relationships of the yellow-pigmented hydrogen-oxidizing species Pseudomonas flava, Pseudomonas pseudoflava, Pseudomonas palleronii, Pseudomonas taeniospiralis, and "Pseudomonas carboxydoflava," which are all members of the acidovorans ribosomal ribonucleic acid (rRNA) complex in rRNA superfamily III, were studied by using deoxyribonucleic acid (DNA):rRNA hybridization, immunotyping, numerical analysis of biochemical and auxanographic features, polyacrylamide gel electrophoresis of cellular proteins, numerical analysis of fatty acid patterns, and DNA:DNA hybridization. Our results show that these five yellow-pigmented hydrogen-oxidizing Pseudomonas species are more closely related to each other than to other taxa belonging to the acidovorans rRNA complex. We propose the transfer of these species to a new genus, Hydrogenophaga, with the following four species: Hydrogenophaga flava (formerly Pseudomonas flava), Hydrogenophaga pseudoflava (to accommodate both Pseudomonas pseudoflava and "Pseudomonas carboxydoflava"), Hydrogenophaga taeniospiralis (formerly Pseudomonas taeniospiralis), and Hydrogenophaga palleronii (formerly Pseudomonas palleronii). The type species is $H$. flava, with monotype strain DSM 619 (= LMG $2185=$ CCUG 1658). Because $\boldsymbol{H}$. flava grows slowly and unreliably, but is genotypically and protein electrophoretically very similar to $\boldsymbol{H}$. pseudoflava, the latter species can be used as an alternative reference taxon for the new genus. The type strains of $\boldsymbol{H}$. pseudoflava, $\boldsymbol{H}$. taeniospiralis, and $\boldsymbol{H}$. palleronii are strains GA3 (= LMG $5945=$ CCUG 13799), DSM 2082 (= LMG 7170 = CCUG 15921), and Stanier 362t1 (= LMG 2366t1 = CCUG 20334), respectively.
\end{abstract}

The genus Hydrogenomonas was originally created to shelter gram-negative, facultatively autotrophic hydrogen bacteria (34). In 1969 Davis et al. (7) proposed that this genus should be abandoned and transferred the various species to other genera. Because of their deoxyribonucleic acid (DNA) base compositions, their polar flagellation, and their overall phenotypic properties, the yellow-pigmented organism $\mathrm{Hy}$ drogenomonas flava and the nonpigmented organisms $H y$ drogenomonas facilis and Hydrogenomonas ruhlandii were assigned to the genus Pseudomonas. Later, Pseudomonas palleronii was described as an additional yellow-pigmented hydrogen-oxidizing species, differing from Pseudomonas flava in the nature of its carotenoid pigments and its inability to grow on several carbohydrates (8).

Within the phenotypically defined genus Pseudomonas, five ribosomal ribonucleic acid (rRNA) homology groups were delineated by means of DNA:rRNA hybridization (37). Later, De Vos and De Ley (14) extended these five rRNA groups considerably and showed that they are only very remotely interrelated and cannot be maintained in a single genus. This conclusion was confirmed by results from several other techniques $(6,46)$. Most Pseudomonas species are

\footnotetext{
* Corresponding author.
}

located on three rRNA branches; only the Pseudomonas fluorescens rRNA branch in rRNA superfamily II represents the true pseudomonads (14). We consider all of the other Pseudomonas species to be generically misnamed (14). Below all misnamed taxa are indicated by brackets. The yellow-pigmented hydrogen-oxidizing species [Pseudomonas] flava, [Pseudomonas] palleronii, [Pseudomonas] pseudoflava, "[Pseudomonas] carboxydoflava," and [Pseudomonas] taeniospiralis belong to the acidovorans rRNA complex, i.e., rRNA homology group III sensu Palleroni (36). This rRNA complex belongs to rRNA superfamily III (sensu De Ley [10]), which corresponds to the beta subclass of the Proteobacteria (41). In addition, this rRNA complex contains the following species: [Pseudomonas] acidovorans, [Pseudomonas] avenae, [Pseudomonas] cattleyae, [Pseudomonas] delafieldii, [Pseudomonas] facilis, [Pseudomonas] pseudoalcaligenes subsp. citrulli, [Pseudomonas] pseudoalcaligenes subsp. konjaci, [Pseudomonas] rubrilineans, [Pseudomonas] saccharophila, "[Pseudomonas $]$ setariae," [Pseudomonas] testosteroni, Comamonas terrigena, [Alcaligenes] paradoxus, [Alcaligenes] latus, [Rhodocyclus] gelatinosus, and Xylophilus ampelinus $(15,16,44)$. [Pseudomonas] acidovorans and [Pseudomonas] testosteroni were recently transferred to the genus Comamonas (42).

So far, within the acidovorans rRNA complex, labeled 
rRNAs have been available from the type strains of only Comamonas acidovorans, [Alcaligenes] paradoxus, and $X y$ lophilus ampelinus. Hybridization of these rRNAs with DNAs from strains belonging to the acidovorans rRNA complex resulted in delineation of three rRNA subbranches linked at a $T_{m(e)}$ level $\left[T_{m(e)}\right.$ is the temperature, in degrees Celsius, at which one-half of the DNA:rRNA duplex is denatured] of $76.2 \pm 0.7^{\circ} \mathrm{C}$ and containing one species each. All of the other species of the acidovorans rRNA complex are presently located on the $T_{m(e)}$ dendrogram at the branching level of these three rRNA subbranches $(16,44)$. Within this phenotypically very diverse group, some taxa may be more closely related to each other. We are in the process of revealing these possible subgroups by using a repeated process of rRNA preparation from new strains and DNArRNA hybridization. The combination of DNA:rRNA hybridization data with the results of other techniques should provide a clearer view of the relationships within the acidovorans rRNA complex. In this study, we used a broad spectrum of methods to investigate the taxonomy of the yellow-pigmented hydrogen-oxidizing [Pseudomonas] species belonging to the acidovorans rRNA complex. We propose the creation of a new genus, Hydrogenophaga, for these organisms.

\section{MATERIALS AND METHODS}

Bacterial strains. The strains which we used are listed in Table 1. "[Pseudomonas] gazotropha" was grown on PSS medium, which contained $1 \%$ (wt/vol) neutralized bacteriological peptone (type L34; Oxoid Ltd., London, England), $0.1 \%(\mathrm{wt} / \mathrm{vol})$ succinic acid, $0.1 \%(\mathrm{wt} / \mathrm{vol})\left(\mathrm{NH}_{4}\right)_{2} \mathrm{SO}_{4}, 0.1 \%$ (wt/vol) $\mathrm{MgSO}_{4} \cdot 7 \mathrm{H}_{2} \mathrm{O}, 0.0002 \%$ (wt/vol) $\mathrm{FeCl}_{3} \cdot 6 \mathrm{H}_{2} \mathrm{O}$, and $0.0002 \%(\mathrm{wt} / \mathrm{vol}) \mathrm{MnSO}_{4} \cdot \mathrm{H}_{2} \mathrm{O}$; the $\mathrm{pH}$ was adjusted to 7.0 with $1 \mathrm{M} \mathrm{KOH}$. The media used for growth of [Rhodocyclus] gelatinosus and Xylophilus ampelinus have been described previously (44); all other strains were grown on nutrient agar $(0.1 \%[\mathrm{wt} / \mathrm{vol}]$ beef extract, $0.2 \%$ [wt $/ \mathrm{vol}]$ yeast extract, $0.5 \%$ [wt/vol] $\mathrm{NaCl}, 0.5 \%$ [wt/vol] peptone, $2 \%$ [wt/vol] agar, $\mathrm{pH}$ 7.4). For fatty acid analysis, cells were grown for 40 $\mathrm{h}$ on Columbia agar (Oxoid) containing $5 \%(\mathrm{vol} / \mathrm{vol})$ defibrinated horse blood. All strains except Xylophilus ampelinus NCPPB $2217^{\mathrm{T}}(\mathrm{T}=$ type strain $)$ were grown at $28^{\circ} \mathrm{C}$; Xylophilus ampelinus NCPPB $2217^{\mathrm{T}}$ was grown at $24^{\circ} \mathrm{C}$.

Preparation of high-molecular-weight DNA. Cells were grown in Roux flasks for 2 to 3 days. DNA was isolated by the method of Marmur (29).

DNA base composition. The average guanine-plus-cytosine $(\mathrm{G}+\mathrm{C})$ contents were determined by the thermal denaturation method (13) and were calculated by using the equation of Marmur and Doty (30), as modified by De Ley (9).

DNA:rRNA hybridization. DNA was further purified by $\mathrm{CsCl}$ gradient centrifugation (12). Fixation of thermally denatured DNA on cellulose nitrate filters and chemical estimation of the amount of filter-fixed DNA were performed as described previously $(12,43) .\left[{ }^{3} \mathrm{H}\right] \mathrm{rRNAs}$ from [Pseudomonas] palleronii Stanier $362 \mathrm{t} 1^{\mathrm{T}}$ and Comamonas terrigena NCIB $8193^{\mathrm{T}}$ and $\left[{ }^{14} \mathrm{C}\right] \mathrm{rRNA}$ from [Pseudomonas] pseudoflava $\mathrm{GA}^{\mathrm{T}}$ were isolated and purified as described by De Ley and De Smedt (12). Purified 23S [ $\left.{ }^{3} \mathrm{H}\right]$ rRNA from Comamonas acidovorans Stanier $14^{\mathrm{T}}$ and $16 \mathrm{~S}\left[{ }^{14} \mathrm{C}\right] \mathrm{rRNA}$ from [Alcaligenes] paradoxus ATCC $17713 \mathrm{t1}^{\mathrm{T}}$ were available in our research group $(15,16)$. Hybridizations between labeled $16 \mathrm{~S}$ or $23 \mathrm{~S}$ rRNA and filter-fixed DNA were carried out as described previously (12). Each hybrid was characterized by its $T_{m(e)}$ and by the percentage of rRNA binding (the amount of rRNA [in micrograms] bound to $100 \mu \mathrm{g}$ of filter-fixed DNA after ribonuclease treatment).

DNA:DNA hybridization. The degree of binding, expressed as a percentage, was determined spectrophotometrically by using the initial renaturation rate method (11). We used a model 2600 spectrophotometer (Gilford Instrument Laboratories, Inc., Oberlin, Ohio) equipped with a thermostatically controlled cuvette chamber and a model $7225 \mathrm{~A}$ plotter (Hewlett-Packard Co., Palo Alto, Calif.). Renaturations were performed in $2 \times \mathrm{SSC}(1 \times \mathrm{SSC}$ is $0.15 \mathrm{M} \mathrm{NaCl}$ plus $0.015 \mathrm{M}$ sodium citrate, $\mathrm{pH} 7.0$ ) at the optimal renaturation temperature of $80.9^{\circ} \mathrm{C}$ and with a total DNA concentration of $0.101 \mathrm{mM}$ base pairs. Degrees of binding of $25 \%$ or less indicate no significant DNA homology.

Taxonomic immunotyping. The preparation of antisera by immunizing rabbits with bacterial extracts in Freund incomplete adjuvant and the immunodiffusion technique have been described previously $(16,17)$.

Morphological and biochemical features. To determine morphological and biochemical features, we used the methods described by De Vos et al. (16). Nitrite reduction was tested as described by Rossau et al. (39).

Carbon substrate assimilation tests. API $50 \mathrm{CH}$, API $50 \mathrm{AO}$, and API 50AA galleries (API System S.A., MontalieuVercieu, France) were used to test the assimilation of 147 organic compounds as sole carbon sources. The experimental procedure which we used has been described previously (23). For "[Pseudomonas] gazotropha" $0.1 \mathrm{M}$ potassium phosphate buffer ( $\mathrm{pH} 7$ ) was used to prepare the medium for the auxanographic tests instead of sodium phosphate buffer, and the API galleries were incubated at $28^{\circ} \mathrm{C}$ instead of $30^{\circ} \mathrm{C}$.

Numerical analysis of phenotypic features. The scoring of the auxanographic and biochemical tests has been described previously (39). Of the 251 features tested, 192 were used in the numerical analysis. The API $20 \mathrm{NE}$ tests ( 21 features) were not included in the computer analysis as they duplicated other tests, and 38 other features were omitted because all 38 strains tested were either negative or displayed the same positive value. The levels of interstrain similarity were calculated by using the Gower similarity coefficient $\left(\mathrm{S}_{\mathrm{G}}\right)(40)$. Cluster analysis by the unweighted average pair group method (40) was performed with the CLUSTAN 2.1 program of Wishart (45) on the Siemens model 7551 computer of the Centraal Digitaal Rekencentrum, Rijksuniversiteit Ghent, Ghent, Belgium. The reproducibility of the clustering was estimated by including duplicate tests for seven strains.

Polyacrylamide gel electrophoresis of proteins. All strains were grown on nutrient agar at $28^{\circ} \mathrm{C}$ for $40 \mathrm{~h}$ in Roux flasks. Whole-cell protein extracts were prepared, and sodium dodecyl sulfate-polyacrylamide gel electrophoresis was performed by using small modifications of the procedure of Laemmli (27), as described previously (24). The normalized densitometric traces of the protein electrophoretic patterns were grouped by numerical analysis, using the Pearson product moment correlation coefficient $(r)$ and the techniques described by Pot et al. (38).

Gas chromatography of cellular fatty acids. The following strains were examined for cellular fatty acid composition: [Pseudomonas] flava DSM 619 ${ }^{\mathrm{T}}$; [Pseudomonas] palleronii Stanier $362 \mathrm{t} 1^{\mathrm{T}}$, Stanier $362 \mathrm{t} 2^{\mathrm{T}}$, Stanier $366, \mathrm{RH} 2, \mathrm{Z14}, \mathrm{Z17}$, and $\mathrm{Z} 32 ;[$ Pseudomonas $]$ pseudoflava $\mathrm{GA}^{\mathrm{T}}, \mathrm{GA} 2$, and GA4; "[Pseudomonas] carboxydoflava" DSM 1084"; [Pseudomonas] taeniospiralis DSM 2082 ${ }^{\mathrm{T}}$; [Pseudomonas] delafieldii ATCC $17505^{\mathrm{T}}$; [Pseudomonas] facilis ATCC $11228^{\mathrm{T}}$; [Pseudomonas] avenae NCPPB $1011^{\mathrm{T}}$; “[Pseudomonas] gazotro- 


\begin{tabular}{|c|c|c|c|}
\hline Species & Strain $^{a}$ & Other strain designation(s) & Source and place and year of isolation \\
\hline \multicolumn{4}{|l|}{$\begin{array}{l}\text { Organisms assigned to the genus } \\
\text { Hydrogenophaga }\end{array}$} \\
\hline $\begin{array}{l}\text { "[Pseudomonas] carboxydo- } \\
\text { flava" }\end{array}$ & DSM $1084^{\mathrm{T}}$ & $\begin{array}{l}\text { LMG } 7584^{\mathrm{T}}, \text { CCUG } 20741^{\mathrm{T}}, \mathrm{Z}-1107^{\mathrm{T}} \\
\left(=\mathrm{LMG} 8355^{\mathrm{T}}=\text { CCUG } 22764^{\mathrm{T}}\right)\end{array}$ & Mud and soil, River Moskwa, USSR \\
\hline $\begin{array}{l}\text { "[Pseudomonas }] \text { carboxydo- } \\
\text { flava" }\end{array}$ & $\mathrm{Z}-1607$ & LMG 8356, CCUG 22765 & $\begin{array}{l}\text { Soil near River Nischenka, Moscow } \\
\text { area, USSR }\end{array}$ \\
\hline [Pseudomonas] flava & DSM $619^{\mathrm{T}}$ & LMG $2185^{\mathrm{T}}$, CCUG $1658^{\mathrm{T}}$, ATCC $33667^{\mathrm{T}}$ & Mud from ditch, 1942 \\
\hline [Pseudomonas] palleronii & Stanier $362 t 1^{\mathrm{T} b}$ & $\begin{array}{l}\text { LMG 2366t1 } 1^{\mathrm{T} b}\left(=\text { CCUG } 20334^{\mathrm{T}}\right), \text { ATCC } \\
17724^{\mathrm{T}}\left(=\text { CCUG } 1780^{\mathrm{T}}\right)\end{array}$ & $\begin{array}{l}\text { Water enriched for hydrogen bacteria } \\
\text { in an atmosphere containing } 6 \% \mathrm{O}_{2}\end{array}$ \\
\hline [Pseudomonas $]$ palleronii & Stanier $362 \mathrm{t} 2^{\mathrm{T} h}$ & $\begin{array}{l}\text { LMG 2366t } 2^{\mathrm{T} b}\left(=\text { CCUG } 20335^{\mathrm{T}}\right), \text { ATCC } \\
17724^{\mathrm{T}}\left(=\text { CCUG } 1780^{\mathrm{T}}\right)\end{array}$ & $\begin{array}{l}\text { Water enriched for hydrogen bacteria } \\
\text { in an atmosphere containing } 6 \% \mathrm{O}_{2}\end{array}$ \\
\hline [Pseudomonas] palleronii & Stanier 366 & $\begin{array}{l}\text { LMG 6346, CCUG 17387, CCUG 20336, } \\
\text { ATCC } 17728\end{array}$ & $\begin{array}{l}\text { Water enriched for hydrogen bacteria } \\
\text { in an atmosphere containing } 6 \% \mathrm{O}_{2}\end{array}$ \\
\hline [Pseudomonas] palleronii & RH2 & LMG 6348, CCUG 20338 & $\begin{array}{l}\text { Göttingen, Federal Republic of } \\
\text { Germany }\end{array}$ \\
\hline [Pseudomonas] palleronii & Z14 & LMG 6349, CCUG 21796 & Russia \\
\hline [Pseudomonas] palleronii & $\mathrm{Z} 17$ & LMG 6350, CCUG 21797 & Russia \\
\hline [Pseudomonas] palleronii & $\mathrm{Z} 32$ & LMG 6347, CCUG 17388, CCUG 20337 & Russia \\
\hline [Pseudomonas] pseudoflava & $\mathrm{GA} 3^{\mathrm{T}}$ & LMG $5945^{\mathrm{T}}$, CCUG $13799^{\mathrm{T}}$, ATCC $33668^{\mathrm{T}}$ & $\begin{array}{l}\text { Water, River Weende, Federal } \\
\text { Republic of Germany }\end{array}$ \\
\hline [Pseudomonas] pseudoflava & GA2 & LMG 6351, CCUG 17389, CCUG 20339 & \\
\hline [Pseudomonas] pseudoflava & GA4 & LMG 6352, CCUG 17390, CCUG 20340 & \\
\hline [Pseudomonas] taeniospiralis & DSM $2082^{\mathrm{T}}$ & LMG $7170^{\mathrm{T}}$, CCUG $15921^{\mathrm{T}}$ & Soil, Spain \\
\hline \multicolumn{4}{|l|}{ Reference organisms } \\
\hline [Pseudomonas] avenae & NCPPB $1011^{\mathrm{T}}$ & LMG $2117^{\mathrm{T}}$, CCUG $15838^{\mathrm{T}}$, ATCC $19860^{\mathrm{T}}$ & Zea mays, United States, 1958 \\
\hline $\begin{array}{l}{[\text { Pseudomonas }] \text { cattleyae }} \\
{[\text { Pseudomonas }] \text { delafieldii }}\end{array}$ & $\begin{array}{l}\text { NCPPB } 961^{\top} \\
\text { ATCC } 17505^{\mathrm{T}}\end{array}$ & $\begin{array}{l}\text { LMG } 5286^{\mathrm{T}} \text {, CCUG } 21975^{\mathrm{T}}, \text { ATCC } 33619^{1} \\
\text { LMG } 5943^{\mathrm{T}} \text {, CCUG } 1779^{\mathrm{T}}\end{array}$ & $\begin{array}{l}\text { Soil with PHB as the sole carbon } \\
\text { source }^{c}\end{array}$ \\
\hline [Pseudomonas] delafieldii & Stanier $134 \mathrm{t} 1^{b}$ & LMG 1792t1 ${ }^{b}$, CCUG 14277, ATCC 17506 & $\begin{array}{l}\text { Soil with PHB as the sole carbon } \\
\text { source }\end{array}$ \\
\hline [Pseudomonas] delafieldii & ATCC 17508 & LMG 5944, CCUG 14478 & $\begin{array}{l}\text { Soil with PHB as the sole carbon } \\
\text { source }\end{array}$ \\
\hline [Pseudomonas] facilis & ATCC $11228^{\mathrm{T}}$ & LMG $2193^{\mathrm{T}}$, CCUG $2113^{\mathrm{T}}$ & Lawn soil, United States \\
\hline [Pseudomonas] facilis & ATCC 15376 & LMG 2194, CCUG 14278 & \\
\hline [Pseudomonas] facilis & DSM 550 & LMG 6598, CCUG 15919, ATCC 17695 & Lawn soil \\
\hline "[Pseudomonas $]$ gazotropha" & DSM $1085^{\mathrm{T}}$ & LMG $7583^{\mathrm{T}}$, CCUG $20742^{\mathrm{T}}$, CCUG $21978^{\mathrm{T}}$ & Mud, River Moskwa, USSR \\
\hline [Pseudomonas] rubrilineans & NCPPB $920^{\mathrm{T}}$ & LMG $2281^{\mathrm{T}}$, CCUG $15837^{\mathrm{T}}$, ATCC $19307^{\mathrm{T}}$ & $\begin{array}{l}\text { Saccharum officinarum cv. R445, } \\
\text { Réunion, } 1960\end{array}$ \\
\hline [Pseudomonas] saccharophila & ATCC $15946^{\mathrm{T}}$ & LMG $2256^{\mathrm{T}}$, LMG $7831^{\mathrm{T}}$ & Mud from a stagnant pool \\
\hline "[Pseudomonas] setariae" & NCPPB $1392^{\mathrm{T}}$ & LMG $1806^{\mathrm{T}}$, CCUG $15836^{\mathrm{T}}$, ATCC $19882^{\mathrm{T}}$ & Oryza sativa, Japan, 1955 \\
\hline Comamonas acidovorans & Stanier $14^{\mathrm{T}}$ & LMG $1226^{\mathrm{T}}$, ATCC $15668^{\mathrm{T}}$, CCUG $14481^{\mathrm{T}}$ & $\begin{array}{l}\text { Soil enriched with acetamide, Delft, } \\
\text { The Netherlands, } 1926\end{array}$ \\
\hline Comamonas acidovorans & ATCC 17406 & LMG 1790, CCUG 15340 & Soil enriched with $p$-hydroxybenzoate \\
\hline Comamonas acidovorans & ATCC 17476 & 1, CCUG 15337 & Great B \\
\hline Comamonas acidovorans & CCUG 274B & LMG 7098 & Urine, male, Göteborg, Sweden, 1968 \\
\hline Comamonas terrigena & NCIB $8193^{\mathrm{T}}$ & $\begin{array}{l}\text { LMG } 1253^{\mathrm{T}}, \text { CCUG } 2185^{\mathrm{T}}(=\text { LMG } \\
\left.5929^{\mathrm{T}}\right), \text { CCUG } 15327^{\mathrm{T}}, \text { ATCC } 8461^{\mathrm{T}}\end{array}$ & Hay infusion filtrate, United States \\
\hline Comamonas terrigena & NCIB 2581 & LMG 1249, CCUG 2474 & Soil \\
\hline Comamonas terrigena & CCUG 12940 & G 5520 & Blood, 1982 \\
\hline Comamonas terrigena & NCIB 2582 & LMG 1251, CCUG 2475, ATCC 14636 & Soil \\
\hline Comamonas testosteroni & NCTC $10698^{\mathrm{T}}$ & LMG $1786^{\mathrm{T}}$, CCUG $1426^{\mathrm{T}}$, ATCC $11996^{\mathrm{T}}$ & Soil, Berkeley, Calif. \\
\hline Comamonas testosteroni & ATCC 17407 & LMG 1787, CCUG 15341 & Soil enriched with anthranilate \\
\hline Comamonas testosteroni & ATCC 17409 & LMG 1788, CCUG 15339 & $\begin{array}{l}\text { Soil enriched with kynurenate, } \\
\text { Berkeley, Calif., } 1963\end{array}$ \\
\hline [Alcaligenes] latus & Palleroni $\mathrm{H}-4^{\mathrm{T}}$ & LMG $3321^{\mathrm{T}}$, CCUG $10983^{\mathrm{T}}$, ATCC $29712^{\mathrm{T}}$ & Soil, California \\
\hline [Alcaligenes] paradoxus & ATCC $17713 \mathrm{tI}^{\mathrm{T} b}$ & LMG $1797 \mathrm{t1}^{\mathrm{T} b}$, CCUG $1777^{\mathrm{T}}$ & $\begin{array}{l}\text { Soil in mineral medium under an } \\
\text { atmosphere containing } 91 \% \mathrm{H}_{2}, 4 \% \\
\mathrm{O}_{2} \text {, and } 5 \% \mathrm{CO}_{2}\end{array}$ \\
\hline [Alcaligenes] paradoxus & ATCC 17712 & LMG 3572, CCUG 15916 & $\begin{array}{l}\text { Soil in atmosphere containing } \mathrm{H}_{2}, 6 \% \\
\mathrm{O}_{2} \text { and } 5 \% \mathrm{CO}_{2}\end{array}$ \\
\hline [Alcaligenes] paradoxus & ATCC $17549 \mathrm{t}^{b}$ & LMG $1796 \mathrm{t}^{b}$, CCUG 1778 & Soil enriched with panthotenate \\
\hline [Rhodocyclus] gelatinosus & NCIB $8290^{\mathrm{T}}$ & $\begin{array}{l}\text { LMG } 4311^{\mathrm{T}}, \text { ATCC } 17011^{\mathrm{T}}, \text { CCUG } \\
15841^{\mathrm{T}}, \text { CCUG } 21977^{\mathrm{T}}\end{array}$ & Acetate enrichment, $\mathrm{pH} 6.6$ \\
\hline Xylophilus ampelinus & NCPPB $2217^{\mathrm{T}}$ & LMG $5856^{\mathrm{T}}$, ATCC $33914^{\mathrm{T}}$, CCUG $21976^{\mathrm{T}}$ & Vitis vinifera var. sultana, Crete, 1966 \\
\hline
\end{tabular}


pha" DSM 1085 ; Comamonas acidovorans Stanier $14^{\mathrm{T}}$, ATCC 17406, and ATCC 17476; Comamonas terrigena NCIB $8193^{\mathrm{T}}$, NCIB 2581, NCIB 2582, and CCUG 12940; Comamonas testosteroni NCTC $10698^{\mathrm{T}}$, ATCC 17407, and ATCC 17409; [Alcaligenes] paradoxus ATCC 17713t1 ${ }^{\mathrm{T}}$, ATCC 17712, and ATCC 17549t1; [Alcaligenes] latus Palleroni $\mathrm{H}-4^{\mathrm{T}}$; and [Rhodocyclus] gelatinosus $\mathrm{NCIB} 8290^{\mathrm{T}}$. The strains were grown on Columbia blood agar as described above, washed, harvested, freeze-dried, and methanolyzed (both alkaline and acidic) as described previously $(18,19)$. The resulting fatty acid methyl esters were analyzed on a gas chromatograph equipped with a flame ionization detector as described previously (39). The hydroxylated fatty acids were separated from the nonhydroxylated fatty acids on a silica BOND ELUT extraction column (Analytichem International, Harbor City, Calif.) and analyzed and identified separately by gas chromatography-mass spectrometry (Iontrap 700 instrument; Finnigan, San Jose, Calif.) after trifluoroacetylation and trimethylsilylation (31).

Numerical analysis of gas chromatographic data. Principal component analysis was carried out by using the soft independent modeling of class analogy method (47), as previously described (20). The software program (in a PC-DOS version) was obtained from Pattern Recognition Systems, Bergen, Norway.

Determination of quinone and polyamine contents. Quinones were analyzed by thin-layer chromatography as described by Auling et al. (3), and polyamines were analyzed by high-performance liquid chromatography as described by Busse and Auling (5).

\section{RESULTS}

DNA base composition. The average $G+C$ values of the strains studied are shown in Table 2.

DNA:rRNA hybridizations. The specific activities of the $23 \mathrm{~S}\left[{ }^{14} \mathrm{C}\right] \mathrm{rRNA}$ fraction from [Pseudomonas] pseudoflava $\mathrm{GA}^{\mathrm{T}}$, the $23 \mathrm{~S}\left[{ }^{3} \mathrm{H}\right] \mathrm{rRNA}$ fraction from [Pseudomonas] palleronii Stanier $362 \mathrm{t1}^{\mathrm{T}}$, and the $16 \mathrm{~S}$ and $23 \mathrm{~S}\left[{ }^{3} \mathrm{H}\right] \mathrm{rRNA}$ fractions from Comamonas terrigena NCIB $8193^{\mathrm{T}}$ were $1,757,82,684,14,236$, and $21,426 \mathrm{cpm} / \mu \mathrm{g}$ of rRNA, respectively. The results of the DNA:rRNA hybridizations are shown in Table 2 and are presented as a dendrogram based on $T_{m(e)}$ values in Fig. 1. Our results allow the delineation of three new rRNA groups within the acidovorans rRNA complex. The first group, formed by the four Comamonas terrigena strains, is linked to the other taxa in the acidovorans rRNA complex at the branching level of the three existing rRNA subbranches $\left[T_{m(e)}, 76.1 \pm 1.1^{\circ} \mathrm{C}\right]$ and thus constitutes a new rRNA subbranch. The second rRNA group exclusively comprises [Pseudomonas] palleronii strains, and the third one is formed by [Pseudomonas] pseudoflava, "[Pseudomonas] carboxydoflava," and [Pseudomonas] flava strains. Reciprocal hybridizations between the [Pseudomonas] palleronii and [Pseudomonas] pseudoflava rRNA groups yielded a mean clustering level of $78.0 \pm$ $0.7^{\circ} \mathrm{C}$. Hybridizations between rRNAs from both [Pseudomonas] palleronii Stanier $362 \mathrm{t} 1^{\mathrm{T}}$ and [Pseudomonas] pseudoflava $\mathrm{GA}^{\mathrm{T}}$ and DNAs from reference strains belonging to the acidovorans rRNA complex showed that these rRNAs are linked to the other four rRNA subbranches at the branching level of $76.1 \pm 1.1^{\circ} \mathrm{C}$. Therefore we consider the [Pseudomonas] palleronii and [Pseudomonas] pseudoflava rRNA groups to be a single bifurcated rRNA subbranch. [Pseudomonas] taeniospiralis DSM $2082^{\mathrm{T}}$ is located on this rRNA subbranch at the bifurcation level (Table 2).
DNA:DNA hybridizations. The results of our DNA:DNA hybridizations are summarized in Fig. 2. We distinguished two DNA homology groups, one formed by the [Pseudomonas] palleronii strains and the other formed by the [Pseudomonas] pseudoflava, "[Pseudomonas] carboxydoflava," and [Pseudomonas] flava strains. Within the latter DNA homology group, [Pseudomonas] flava DSM $619^{\mathrm{T}}$ was the most aberrant strain (degree of binding, 48 to $62 \%$ ). The members of the [Pseudomonas] palleronii DNA homology group showed no significant DNA binding with the type strains of [Pseudomonas] pseudoflava, "[Pseudomonas] carboxydoflava," [Pseudomonas] flava, and [Pseudomonas] taeniospiralis. [Pseudomonas] taeniospiralis showed no significant DNA binding with representative strains of any of the other yellow-pigmented hydrogen-oxidizing [Pseudomonas] species.

Immunotyping properties. Our immunotyping results are summarized in Table 3. [Pseudomonas] flava, [Pseudomonas] pseudoflava, "[Pseudomonas] carboxydoflava," and [Pseudomonas] taeniospiralis were very similar to each other and could easily be separated from [Pseudomonas] palleronii. [Pseudomonas] pseudoflava and [Pseudomonas] flava gave different precipitation patterns of similar magnitude. The antiserum of [Pseudomonas] pseudoflava revealed a fairly high level of relatedness between this species and [Pseudomonas] palleronii. By extending the time of diffusion, the antiserum of [Pseudomonas] palleronii confirmed this observation. [Pseudomonas] delafieldii appeared to be the closest immunological neighbor of the yellow-pigmented hydrogen oxidizers.

Numerical analysis of phenotypic features. A total of 13 representative strains of the yellow-pigmented hydrogenoxidizing [Pseudomonas] species and a number of reference strains belonging to the acidovorans rRNA complex were compared by performing a numerical analysis of auxanographic and biochemical features. Under our test conditions [Alcaligenes] latus Palleroni $\mathrm{H}-4^{\mathrm{T}}$ did not grow on any of the substrates of the auxanographic galleries and was therefore excluded from the numerical analysis. Xylophilus ampelinus was not included either because this organism requires special incubation conditions which would have produced imcompatible results. Strains tested in duplicate clustered, on the average, at an $S_{\mathrm{G}}$ value of $95 \%$ (10 sets of comparisons, with one exceptional minimum having an $\mathrm{S}_{\mathrm{G}}$ value of $90 \%$ ). The following phena separated at $\mathrm{S}_{\mathrm{G}}$ values of more than 79\% (Fig. 3): [Pseudomonas] pseudoflava and "[Pseudomonas] carboxydoflava"; [Pseudomonas] palleronii; Comamonas spp.; [Pseudomonas] facilis and [Pseudomonas] delafieldii; a phenon formed by the type strains of [Pseudomonas] avenae, [Pseudomonas] rubrilineans, [Pseudomonas] cattleyae, and "[Pseudomonas] setariae"; and [Alcaligenes] paradoxus. [Pseudomonas] flava and [Pseudomonas] taeniospiralis were linked to the [Pseudomonas] pseudoflava-"[Pseudomonas] carboxydoflava" phenon at an $\mathrm{S}_{\mathrm{G}}$ value of 74\%. "[Pseudomonas] gazotropha" and [Rhodocyclus] gelatinosus occupy separate positions on the dendrogram.

Protein electrophoresis. Above an $r$ value of 0.8 the following two electrophoretic groups of yellow-pigmented hydrogen-oxidizing species could be delineated: one formed by the [Pseudomonas] palleronii strains and the other formed by the [Pseudomonas] pseudoflava and "Pseudomonas carboxydoflava" strains (Fig. 4). [Pseudomonas] flava DSM $619^{\mathrm{T}}$ and $\left[\right.$ Pseudomonas] taeniospiralis DSM $2082^{\mathbf{T}}$ occupy separate positions on the dendrogram, although the pattern of [Pseudomonas] flava DSM $619^{\mathrm{T}}$ has some overall visual 
TABLE 2. DNA base compositions of strains and parameters of hybrids of DNAs with labeled rRNAs from [Pseudomonas] pseudoflava $\mathrm{GA}^{\mathrm{T}}$, [Pseudomonas] palleronii Stanier $362 \mathrm{t} 1^{\mathrm{T}}$, Comamonas terrigena $\mathrm{NCIB} 8193^{\mathrm{T}}$, Comamonas acidovorans Stanier $14^{\mathrm{T}}$, and [Alcaligenes] paradoxus ATCC $17713 \mathrm{t} 1^{\mathrm{T}}$

\begin{tabular}{|c|c|c|c|c|c|c|c|c|c|c|c|}
\hline \multirow{3}{*}{ DNA from strain: } & \multirow{3}{*}{$\begin{array}{c}\mathrm{G}+\mathrm{C} \\
\text { content } \\
(\mathrm{mol} \%)\end{array}$} & \multicolumn{10}{|c|}{ Hybridized with: } \\
\hline & & \multicolumn{2}{|c|}{ 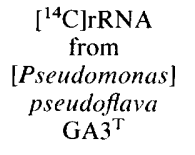 } & \multicolumn{2}{|c|}{$\begin{array}{c}{\left[{ }^{3} \mathrm{H}\right] \mathrm{rRNA}} \\
\text { from } \\
\text { [Pseudomonas] } \\
\text { palleronii } \\
\text { Stanier } 362 \mathrm{t} \mathrm{t}^{\mathrm{T}}\end{array}$} & \multicolumn{2}{|c|}{$\begin{array}{c}{\left[{ }^{3} \mathrm{H}\right] \mathrm{rRNA}} \\
\text { from } \\
\text { Comamonas } \\
\text { terrigena } \\
{\text { NCIB } 8193^{\mathrm{T}}}\end{array}$} & \multicolumn{2}{|c|}{$\begin{array}{l}{\left[{ }^{3} \mathrm{H}\right] \mathrm{rRNA}} \\
\text { from } \\
\text { Comamonas } \\
\text { acidovorans } \\
\text { Stanier } 14^{\mathrm{T}}\end{array}$} & \multicolumn{2}{|c|}{$\begin{array}{c}{\left[{ }^{14} \mathrm{C}\right] \mathrm{rRNA}} \\
\text { from } \\
{[\text { Alcaligenes }]} \\
\text { paradoxus } \\
\text { ATCC } 17713 \mathrm{t} 1^{\mathrm{T}}\end{array}$} \\
\hline & & $\begin{array}{l}T_{m(e)} \\
\left({ }^{\circ} \mathrm{C}\right)\end{array}$ & $\begin{array}{c}\text { rRNA } \\
\text { binding } \\
(\%)\end{array}$ & $\begin{array}{l}T_{m(e)} \\
\left({ }^{\circ} \mathrm{C}\right)\end{array}$ & $\begin{array}{l}\text { rRNA } \\
\text { binding } \\
(\%)\end{array}$ & $\begin{array}{l}T_{m(e)} \\
\left({ }^{\circ} \mathrm{C}\right)\end{array}$ & $\begin{array}{c}\text { rRNA } \\
\text { binding } \\
(\%)\end{array}$ & $\begin{array}{l}T_{m(e)} \\
\left({ }^{\circ} \mathrm{C}\right)\end{array}$ & $\begin{array}{l}\text { rRNA } \\
\text { binding } \\
(\%)\end{array}$ & $\begin{array}{l}T_{m(e)} \\
\left({ }^{\circ} \mathrm{C}\right)\end{array}$ & $\begin{array}{c}\text { rRNA } \\
\text { binding } \\
(\%)\end{array}$ \\
\hline [Pseudomonas] flava DSM $619^{\mathrm{T}}$ & $66.7^{a}$ & 79.6 & 0.08 & 78.2 & 0.07 & & & $75.5^{a}$ & $0.02^{a}$ & $76.0^{b}$ & $0.04^{b}$ \\
\hline [Pseudomonas] pseudoflava $\mathrm{GA}^{\mathrm{T}}$ & 66.4 & 80.8 & 0.04 & 77.4 & 0.09 & 75.2 & 0.09 & 76.0 & 0.08 & & \\
\hline [Pseudomonas] pseudoflava GA2 & 68.6 & 81.1 & 0.06 & 77.7 & 0.08 & & & & & & \\
\hline [Pseudomonas] pseudoflava GA4 & 66.2 & 81.1 & 0.07 & 78.0 & 0.09 & & & & & & \\
\hline "[Pseudomonas] carboxydoflava", DSM $1084^{\mathrm{T}}$ & 66.9 & 80.8 & 0.07 & 77.3 & 0.04 & & & 75.3 & 0.05 & & \\
\hline $\begin{array}{l}\text { "[Pseudomonas }] \text { carboxydoflava" Z-1607 } \\
{[\text { Pseudomonas }] \text { palleronii Stanier } 362 \mathrm{t} 1^{\mathrm{T}}}\end{array}$ & $\begin{array}{l}66.8 \\
67.3\end{array}$ & $\begin{array}{l}79.2 \\
78.1\end{array}$ & $\begin{array}{l}0.04 \\
0.06\end{array}$ & $\begin{array}{l}76.7 \\
80.4\end{array}$ & $\begin{array}{l}0.06 \\
0.07\end{array}$ & 73.4 & 0.06 & $76.0^{a}$ & $0.05^{a}$ & $77.5^{b}$ & $0.06^{b}$ \\
\hline [Pseudomonas] palleronii Stanier $362 \mathrm{t} 2^{\mathrm{T}}$ & 67.3 & 78.4 & 0.04 & 79.1 & 0.07 & & & & & & \\
\hline [Pseudomonas] palleronii Stanier 366 & 67.5 & 77.4 & 0.06 & 79.1 & 0.06 & & & & & & \\
\hline [Pseudomonas] palleronii $\mathrm{RH} 2$ & 68.3 & 79.0 & 0.05 & 79.5 & 0.06 & & & & & & \\
\hline [Pseudomonas] palleronii $\mathrm{Z} 14$ & 68.5 & 77.8 & 0.06 & 79.1 & 0.09 & & & & & & \\
\hline [Pseudomonas] palleronii $\mathrm{Z} 17$ & 68.3 & 77.7 & 0.05 & 78.6 & 0.05 & & & & & & \\
\hline [Pseudomonas] palleronii $\mathrm{Z} 32$ & 68.0 & 79.1 & 0.04 & 79.0 & 0.06 & & & & & & \\
\hline [Pseudomonas] taeniospiralis DSM $2082^{\mathrm{T}}$ & 64.8 & 78.5 & 0.09 & 79.0 & 0.05 & & & 75.0 & 0.04 & & \\
\hline [Pseudomonas] facilis ATCC $11228^{\mathrm{T}}$ & $64.7^{a}$ & 76.8 & 0.06 & 76.3 & 0.06 & 75.0 & 0.08 & $77.0^{a}$ & $0.09^{a}$ & $77.5^{b}$ & $0.07^{b}$ \\
\hline [Pseudomonas] facilis ATCC 15376 & $63.7^{a}$ & 76.1 & 0.06 & 76.0 & 0.06 & & & 76.5 & 0.09 & 78.0 & 0.08 \\
\hline [Pseudomonas] delafieldii ATCC $17505^{\mathrm{T}}$ & $65.6^{b}$ & 75.7 & 0.04 & 75.6 & 0.06 & 75.1 & 0.05 & $77.2^{b}$ & $0.11^{b}$ & $76.6^{b}$ & $0.02^{b}$ \\
\hline [Pseudomonas] delafieldii Stanier 134t1 & 65.3 & 77.0 & 0.07 & 75.3 & 0.09 & & & 78.0 & 0.10 & 77.5 & 0.09 \\
\hline [Pseudomonas] avenae NCPPB $1011^{\mathrm{T}}$ & 69.8 & 76.8 & 0.04 & 75.6 & 0.07 & 75.7 & 0.09 & $76.6^{b}$ & $0.12^{b}$ & $76.5^{b}$ & $0.09^{b}$ \\
\hline [Pseudomonas] saccharophila ATCC $15946^{\mathrm{T}}$ & 69.1 & 72.5 & 0.07 & 73.4 & 0.05 & 71.8 & 0.05 & $72.6^{b}$ & $0.05^{b}$ & 73.4 & 0.04 \\
\hline "[Pseudomonas] gazotropha"' DSM $1085^{\mathrm{T}}$ & 58.0 & 67.3 & & 68.0 & & & & & & & \\
\hline Comamonas terrigena NCIB $8193^{\mathrm{T}}$ & $64.0^{c}$ & 74.2 & 0.41 & 73.9 & 0.14 & 81.1 & 0.32 & $75.9^{c}$ & $0.19^{c}$ & $75.5^{\mathrm{c}}$ & $0.16^{c}$ \\
\hline Comamonas terrigena NCIB 2581 & $65.8^{c}$ & & & & & 79.4 & 0.27 & $75.5^{c}$ & $0.16^{c}$ & $76.0^{c}$ & $0.20^{c}$ \\
\hline Comamonas terrigena CCUG 12940 & 66.1 & & & & & 80.5 & 0.23 & 76.9 & 0.14 & & \\
\hline Comamonas terrigena NCIB 2582 & $66.1^{c}$ & & & & & 81.2 & 0.30 & $76.0^{c}$ & $0.19^{c}$ & $76.0^{c}$ & $0.19^{c}$ \\
\hline Comamonas acidovorans Stanier $14^{\mathrm{T}}$ & $66.6^{a}$ & 73.6 & 0.04 & 73.6 & 0.07 & 75.0 & 0.15 & $80.6^{a}$ & $0.12^{a}$ & $77.0^{c}$ & $0.10^{c}$ \\
\hline Comamonas acidovorans ATCC 17406 & $68.4^{a}$ & & & & & 76.2 & 0.16 & $79.5^{a}$ & $0.12^{a}$ & $76.5^{c}$ & $0.10^{c}$ \\
\hline Comamonas acidovorans ATCC 17476 & $68.4^{a}$ & & & & & 75.8 & 0.16 & $81.0^{a}$ & $0.10^{a}$ & $77.0^{c}$ & $0.10^{c}$ \\
\hline Comamonas testosteroni NCTC $10698^{\mathrm{T}}$ & $62.5^{a}$ & 74.5 & 0.36 & 75.6 & 0.17 & 76.7 & 0.13 & $76.5^{a}$ & $0.17^{a}$ & $76.5^{c}$ & $0.18^{c}$ \\
\hline Comamonas testosteroni ATCC 17407 & $64.5^{a}$ & & & & & 75.9 & 0.14 & $77.5^{a}$ & $0.17^{a}$ & & \\
\hline Comamonas testosteroni ATCC 17409 & $63.0^{a}$ & & & & & 77.7 & 0.24 & $77.5^{a}$ & $0.15^{a}$ & $77.0^{c}$ & $0.17^{c}$ \\
\hline [Alcaligenes] paradoxus ATCC $17713 \mathrm{t} 1^{\mathrm{T}}$ & $67.0^{a}$ & 76.0 & 0.11 & 76.0 & 0.03 & 74.8 & 0.05 & $76.5^{a}$ & $0.03^{a}$ & $81.0^{c}$ & $0.06^{c}$ \\
\hline [Alcaligenes] latus Palleroni $\mathrm{H}-4^{\mathrm{T}}$ & $70.0^{d}$ & 70.2 & 0.05 & 73.4 & 0.10 & 71.6 & 0.15 & $74.5^{b}$ & $0.12^{b}$ & $70.0^{b}$ & $0.11^{b}$ \\
\hline [Rhodocyclus] gelatinosus NCIB $8290^{\mathrm{T}}$ & 70.7 & 70.8 & 0.02 & 71.9 & 0.01 & 73.5 & 0.06 & $74.5^{b}$ & $0.05^{b}$ & $71.0^{b}$ & $0.02^{b}$ \\
\hline Xylophilus ampelinus NCPPB $2217^{\mathrm{T}}$ & $68.4^{b}$ & 75.5 & 0.06 & 75.8 & 0.06 & 75.6 & 0.10 & $76.0^{b}$ & $0.09^{b}$ & 76.2 & 0.06 \\
\hline
\end{tabular}

${ }^{a}$ Data from reference 14 .

${ }^{b}$ Data from reference 44 .

c Data from reference 16 .

${ }^{d}$ Data from reference 22 .

similarities to the patterns of [Pseudomonas] pseudoflava strains. The protein electropherogram of [Pseudomonas] taeniospiralis DSM $2082^{\mathrm{T}}$ is also visually unique. To compare representative reference strains from the acidovorans rRNA complex, we included the following three strains from which labeled rRNAs are available: Comamonas acidovorans Stanier $14^{\mathrm{T}}$, Comamonas terrigena $\mathrm{NCIB} 8193^{\mathrm{T}}$, and [Alcaligenes] paradoxus ATCC $17713 \mathrm{t} 1^{\mathrm{T}}$. Also included were the type strains of the following representative species that are equidistantly related to each of the three abovementioned rRNA subbranches: Comamonas testosteroni, [Pseudomonas] avenae, [Pseudomonas] facilis, and [Pseudomonas] delafieldii. Xylophilus ampelinus NCPPB $2217^{\mathrm{T}}$ cannot be grown on nutrient agar and therefore was not included. There was no resemblance between the protein patterns of the yellow-pigmented hydrogen-oxidizing [Pseu- domonas] species and the pattern of any of the reference strains from the acidovorans rRNA complex investigated (Fig. 4).

Numerical analysis of gas chromatographic cellular fatty acid patterns. Table 4 shows the cellular fatty acid compositions of the species examined. The common pattern was characterized by unbranched fatty acids with chain lengths ranging from 12 to 18 carbon atoms, with palmitoleic acid (16:1), palmitic acid (16:0), and cis-vaccenic acid ( $\Delta 11-18: 1)$ as the most abundant constituents. Generally present, but less abundant, were also lauric acid (12:0), myristic acid (14:0), n-pentadecanoic acid (15:0), n-heptadecanoic acid (17:0), stearic acid (18:0), and cyclopropane-substituted methylene-hexadecanoic acid (17:cyc). The two hydroxylated acids, 3-hydroxy-octanoic acid (3-OH-8:0) and 3-hydroxy-decanoic acid (3-OH-10:0), were more unevenly dis- 


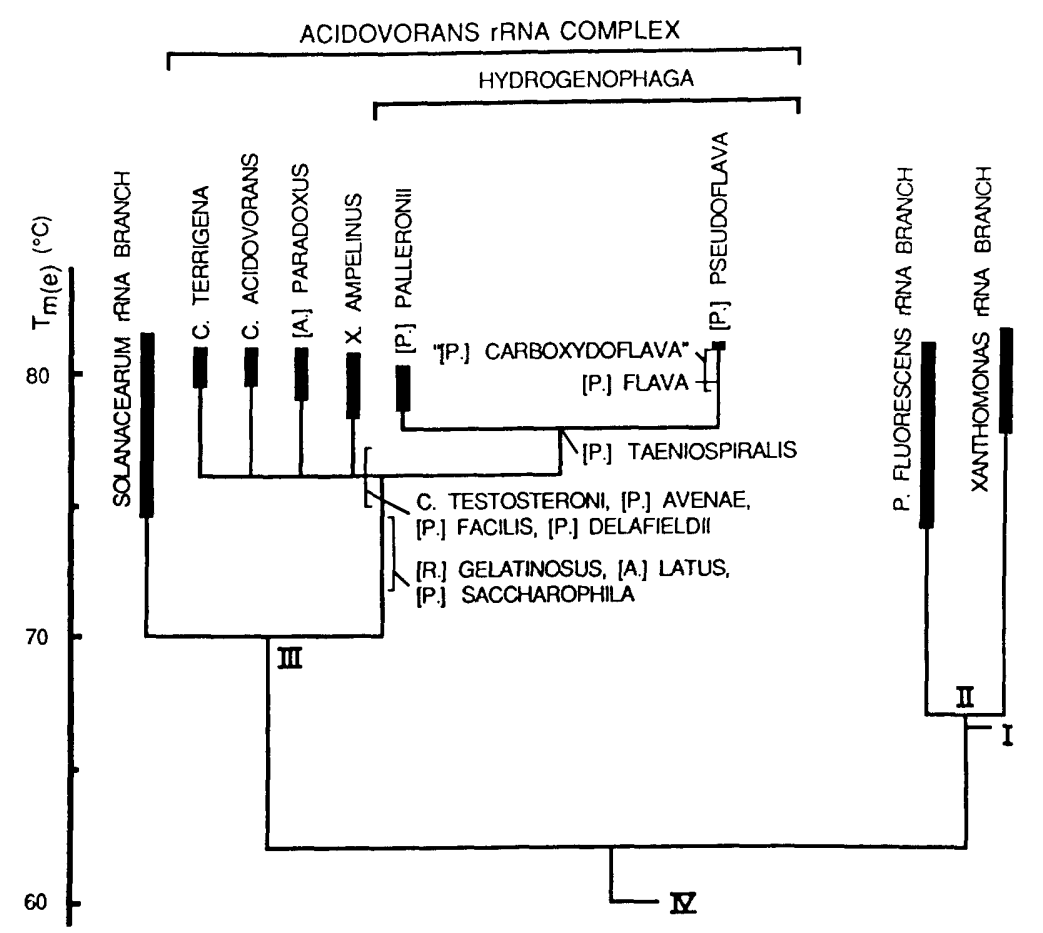

FIG. 1. rRNA cistron similarity dendrogram of the acidovorans rRNA complex. The $T_{m(e)}$ values are from Table 2 and reference 14 . Solid bars represent $T_{m(e)}$ ranges within the individual rRNA branches. The roman numerals indicate the roots of the rRNA superfamilies sensu De Ley (10); I+II, III, and IV correspond to the gamma, beta, and alpha subclasses, respectively, of the Proteobacteria (41). [A.], misnamed Alcaligenes; C., Comamonas; [P.], misnamed Pseudomonas; [R.], misnamed Rhodocyclus; X., Xylophilus.

tributed among the species and represent the main distinguishing fatty acids within the strain material. The species [Pseudomonas] palleronii was most easily distinguished by its relatively high content of $17:$ cyc, its relatively low content of $16: 1$, and the presence of $3-\mathrm{OH}-8: 0$ as the only hydroxylated fatty acid. The latter feature was shared with [Pseudomonas] taeniospiralis, but this species contained less 17:cyc. The three other yellow-pigmented hydrogenoxidizing species, [Pseudomonas] flava, [Pseudomonas] pseudoflava, and "[Pseudomonas] carboxydoflava," showed nearly indistinguishable patterns, with low levels of $17:$ cyc and the presence of the two hydroxylated fatty acids 3-OH-8:0 and 3-OH-10:0 as the main features.

The results of a soft independent modeling of class anal- ogy principal component analysis of the data in Table 4 (except the data for "[Pseudomonas] gazotropha") are shown in Fig. 5. In this figure similarities and dissimilarities are expressed as distances in a two-dimensional plot. The first and second principal components cover 43 and $23 \%$ of the variation, respectively, whereas the third principal component (data not shown) covers $10 \%$. Evidently, the individual fatty acid compositions were too similar for the formation of very distinct clusters, although some separation can be seen. Thus, the strains of [Pseudomonas] palleronii and [Pseudomonas] taeniospiralis group far to the right (Fig. 5, species 4 and 5) and are well separated from the three other yellow-pigmented hydrogen-oxidizing species (Fig. 5, species 1 through 3 ). Most species form relatively homogeneous

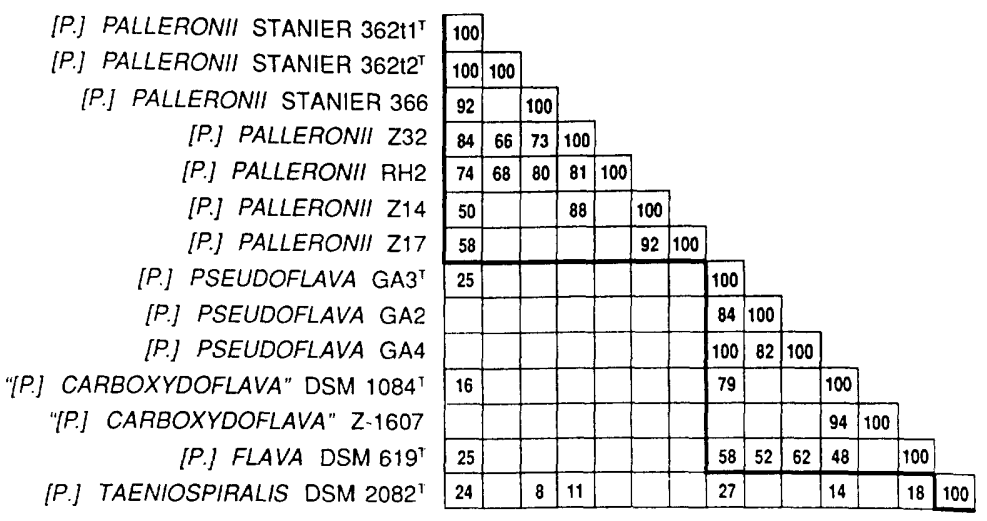

FIG. 2. Average degrees of binding (expressed as percentages) obtained from DNA:DNA hybridizations between representative strains of the yellow-pigmented hydrogen-oxidizing [Pseudomonas] species now assigned to the genus Hydrogenophaga. For abbreviations see the legend to Fig. 1. 
TABLE 3. Immunodiffusion analyses

\begin{tabular}{|c|c|c|c|c|c|}
\hline \multirow[b]{2}{*}{ Antigen from: } & \multicolumn{5}{|c|}{ Antiserum against: } \\
\hline & $\begin{array}{c}\text { [Pseudomonas] } \\
\text { palleronii } \\
\text { CCUG } 1780^{\mathrm{T}}\end{array}$ & $\begin{array}{c}\text { [Pseudomonas] } \\
\text { pseudoflava } \\
\text { CCUG } 13799^{\mathrm{T}}\end{array}$ & $\begin{array}{l}\text { Comamonas } \\
\text { acidovorans } \\
\text { CCUG 274B }\end{array}$ & $\begin{array}{c}\text { Comamonas } \\
\text { terrigena } \\
\text { CCUG } 2185^{\mathrm{T}}\end{array}$ & $\begin{array}{c}\text { [Alcaligenes] } \\
\text { paradoxus } \\
\text { CCUG } 1778\end{array}$ \\
\hline$[$ Pseudomonas $]$ flava DSM $619^{T}$ & $0^{a}$ & 5 & 1 & 1 & 0 \\
\hline$\left[\right.$ Pseudomonas] pseudoflava $\mathrm{GA} 3^{\mathrm{T}}$ & 2 & 7 & 0 & 0 & 0 \\
\hline [Pseudomonas] pseudoflava GA2 & 2 & 6 & 0 & 0 & 0 \\
\hline [Pseudomonas] pseudoflava GA4 & 1 & 6 & 0 & 0 & 0 \\
\hline "[Pseudomonas $]$ carboxydoflava" DSM $1084^{\mathrm{T}}$ & 2 & 6 & 0 & 0 & 0 \\
\hline "[Pseudomonas $]$ carboxydoflava" Z-1607 & 2 & 6 & 0 & 0 & 0 \\
\hline$\left[\right.$ Pseudomonas] palleronii CCUG $1780^{\mathrm{T}}$ & 5 & 3 & 0 & 0 & 0 \\
\hline [Pseudomonas] palleronii Stanier $362 \mathrm{t1}^{\mathrm{T}}$ & 6 & 2 & 0 & 0 & 0 \\
\hline [Pseudomonas] palleronii Stanier $362 \mathrm{t} 2^{\mathrm{T}}$ & 6 & 3 & 0 & 0 & 0 \\
\hline [Pseudomonas] palleronii Stanier 366 & 6 & 2 & 0 & 0 & 0 \\
\hline [Pseudomonas] palleronii $\mathrm{RH} 2$ & 6 & 3 & 0 & 0 & 0 \\
\hline$[$ Pseudomonas $]$ palleronii $\mathrm{Z} 14$ & 6 & 3 & 0 & 1 & 1 \\
\hline [Pseudomonas] palleronii $\mathrm{Z} 17$ & 6 & 4 & 1 & 1 & 1 \\
\hline [Pseudomonas] palleronii $\mathrm{Z} 32$ & 6 & 4 & 0 & 0 & 1 \\
\hline [Pseudomonas] taeniospiralis DSM $2082^{\mathrm{T}}$ & 1 & 5 & 0 & 0 & 0 \\
\hline [Pseudomonas] facilis ATCC $11228^{\mathrm{T}}$ & 1 & 3 & 1 & 0 & 1 \\
\hline [Pseudomonas] facilis ATCC 15376 & 1 & 3 & 2 & 1 & 1 \\
\hline [Pseudomonas] delafieldii ATCC $17505^{\mathrm{T}}$ & 0 & 3 & 0 & 0 & 0 \\
\hline [Pseudomonas] delafieldii Stanier 134t1 & 0 & 4 & 1 & 1 & 1 \\
\hline [Pseudomonas] delafieldii ATCC 17508 & 0 & 2 & 1 & 1 & 0 \\
\hline [Pseudomonas] avenae NCPPB $1011^{\mathrm{T}}$ & 0 & 2 & 1 & 1 & 1 \\
\hline [Pseudomonas] cattleyae NCPPB $961^{\mathrm{T}}$ & 0 & 1 & 0 & 0 & 1 \\
\hline [Pseudomonas] rubrilineans NCPPB $920^{\mathrm{T}}$ & 0 & 2 & 0 & 1 & 1 \\
\hline "[Pseudomonas $]$ setariae"' NCPPB $1392^{\mathrm{T}}$ & 0 & 1 & 1 & 0 & 1 \\
\hline "[Pseudomonas $]$ gazotropha" DMS $1085^{\mathrm{T}}$ & 0 & 0 & 0 & 0 & 0 \\
\hline Comamonas testosteroni $\mathrm{NCTC} 10698^{\mathrm{T}}$ & 0 & 2 & 2 & 3 & 0 \\
\hline Comamonas testosteroni ATCC 17407 & 0 & 2 & 1 & 3 & 0 \\
\hline Comamonas testosteroni ATCC 17409 & 0 & 1 & 1 & 2 & 0 \\
\hline Comamonas terrigena NCIB $8193^{\mathrm{T}}$ & 0 & 0 & 3 & 6 & 0 \\
\hline Comamonas terrigena NCIB 2581 & 0 & 1 & 3 & 5 & 0 \\
\hline Comamonas terrigena CCUG 12940 & 0 & 2 & 3 & 5 & 1 \\
\hline Comamonas terrigena NCIB 2582 & 0 & 1 & 2 & 5 & 0 \\
\hline Comamonas acidivorans Stanier $14^{\mathrm{T}}$ & 1 & 2 & 7 & 1 & 0 \\
\hline Comamonas acidovorans ATCC 17406 & 0 & 1 & 5 & 3 & 0 \\
\hline Comamonas acidovorans ATCC 17476 & 0 & 2 & 6 & 2 & 0 \\
\hline Comamonas acidovorans CCUG 274B & 1 & 2 & 8 & 4 & 1 \\
\hline [Alcaligenes] paradoxus ATCC $17713 \mathrm{t} 1^{\mathrm{T}}$ & 0 & 1 & 0 & 0 & 4 \\
\hline [Alcaligenes] paradoxus ATCC 17712 & 1 & 1 & 1 & 1 & 5 \\
\hline [Alcaligenes] paradoxus CCUG 1778 & 0 & 1 & 0 & 0 & 6 \\
\hline [Alcaligenes] latus Palleroni $\mathrm{H}-4^{\mathrm{T}}$ & 0 & 1 & 2 & 0 & 0 \\
\hline
\end{tabular}

${ }^{a} 0$, No precipitate; 1 or 2 , weak reaction with uncertain interpretation; 3 , weak reaction usually revealing relatedness when serum specificity was high; 4 or 5 , moderate reaction revealing relatedness or identity with unsatisfactory serum; 6,7 , or 8 , strong reaction observed only with closely related strains. Each value is the average of at least two successful immunodiffusion analyses performed under similar conditions.

clusters; however, both the interspecies and intergeneric distances appear to be uncorrelated with the genetic affiliations observed.

Quinone and polyamine contents. A ubiquinone with eight isoprenoid units in the side chain was found in [Pseudomonas] flava DSM 619 ${ }^{\mathrm{T}}$, [Pseudomonas] pseudoflava $\mathrm{GA}^{\mathrm{T}}$, "[Pseudomonas $]$ carboxydoflava" DSM 1084,$[$ Pseudomonas] taeniospiralis DSM $2082^{\mathrm{T}}$, [Pseudomonas] palleronii Stanier $362 \mathrm{t} 1^{\mathrm{T}}$, and "'Pseudomonas] gazotropha" DSM $1085^{\mathrm{T}}$. A quantitative analysis of the polyamines of these strains showed nearly identical patterns. The following data for [Pseudomonas] flava DSM 619 are representative: $1 \mathrm{~g}$ (dry weight) of cells contained $36.3 \mu \mathrm{mol}$ of hydroxyputrescine and $35.6 \mu \mathrm{mol}$ of putrescine. [Pseudomonas] pseudoflava GA3 ${ }^{\mathrm{T}}$ and "[Pseudomonas] carboxydoflava", DSM $1084^{\mathrm{T}}$ contained low amounts of spermidine and spermine in addition. This polyamine pattern is typical for members of superfamily III (5).

\section{DISCUSSION}

Our results show that $[$ Pseudomonas $]$ flava, [Pseudomonas] palleronii, [Pseudomonas] pseudoflava, "[Pseudomonas] carboxydoflava," and [Pseudomonas] taeniospiralis form a separate group within the acidovorans rRNA complex. Our arguments are given below. (i) The hybrids between rRNAs from [Pseudomonas] pseudoflava and [Pseudomonas] palleronii and DNAs from strains of [Pseudomonas] flava, [Pseudomonas] pseudoflava, "[Pseudomonas] carboxydoflava," [Pseudomonas] palleronii, and [Pseudomonas] taeniospiralis have $T_{m(e)}$ values ranging from 77.3 to $81.1^{\circ} \mathrm{C}$. Hybrids between the same rRNAs and DNAs from representative strains of other taxa belonging to the acidovorans rRNA complex have distinctly lower $T_{m(e)}$ values $\left(76.1 \pm 1.1^{\circ} \mathrm{C}\right)$. Therefore, [Pseudomonas] flava, [Pseudomonas] palleronii, [Pseudomonas] pseudoflava, 


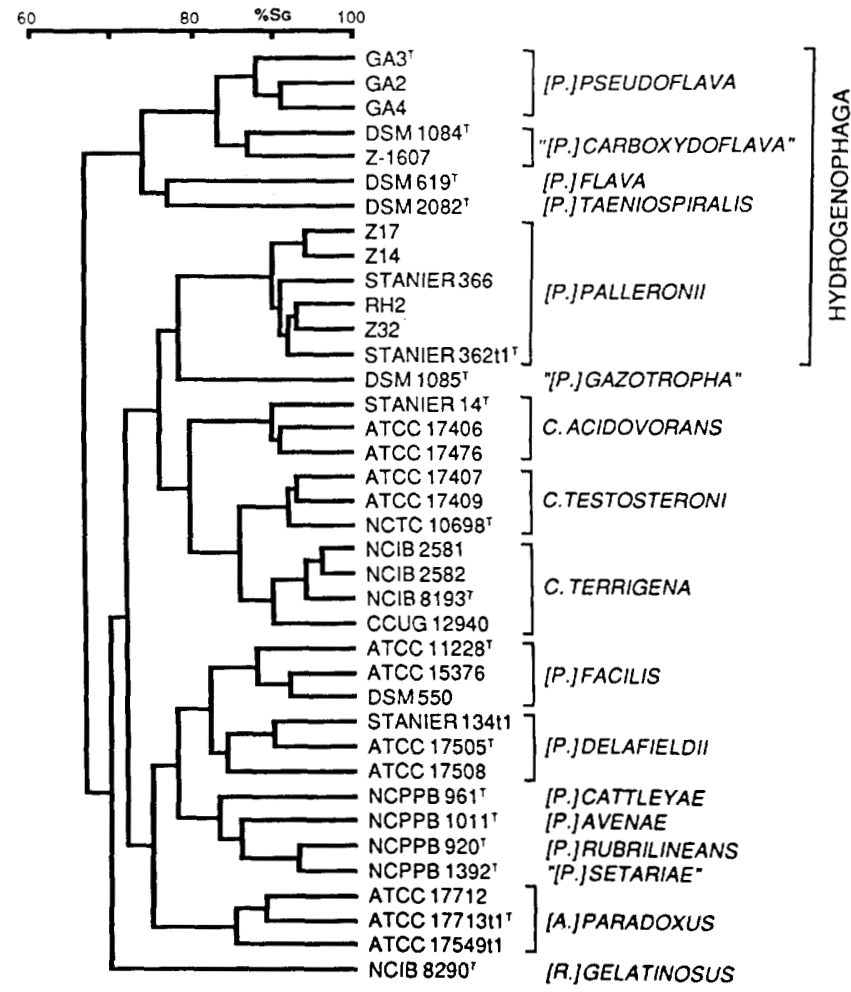

FIG. 3. Dendrogram obtained by unweighted average linkage cluster analysis of $S_{G}$ values. Each of the 38 strains was tested for 251 phenotypic features. For abbreviations see the legend to Fig. 1.
"'Pseudomonas] carboxydoflava," and [Pseudomonas] taeniospiralis are more closely related to each other than to the other taxa belonging to the acidovorans rRNA complex. (ii) High levels of cross-reaction for the group of five species described above versus antisera from [Pseudomonas] palleronii and [Pseudomonas] pseudoflava and low levels of cross-reaction versus the other reference antisera from organisms belonging to the acidovorans rRNA complex were obtained. (iii) [Pseudomonas] flava, [Pseudomonas] pseudoflava, "[Pseudomonas] carboxydoflava," and [Pseudomonas] taeniospiralis formed a separate phenon in our numerical analysis of phenotypic features (Fig. 3). The [Pseudomonas] palleronii phenon is linked with the phenon formed by the four yellow-pigmented hydrogen-oxidizing [Pseudomonas] species at an $\mathrm{S}_{\mathrm{G}}$ value of only $66.8 \%$ (Fig. 3). This is due to the limited number of carbohydrates used for growth by [Pseudomonas] palleronii strains and even more to the great substrate versatility of the other species.

Information from the literature is not opposed to our data. No significant DNA homology was found between [Alcaligenes] paradoxus, [Pseudomonas] facilis, or [Pseudomonas] saccharophila and either [Pseudomonas] palleronii, [Pseudomonas] flava, or [Pseudomonas] pseudoflava (2). The 3-hydroxy fatty acid and quinone patterns were similar in [Pseudomonas] flava, [Pseudomonas] pseudoflava, [Pseudomonas] acidovorans, [Pseudomonas] testosteroni, and Comamonas terrigena; [Pseudomonas] palleronii was placed in a separate group (35). However, these data do not allow conclusions at the generic level.

The acidovorans rRNA complex consists of at least 10 rRNA subbranches, which are very heterogeneous phenotypically and genotypically (Willems, Gillis, and De Ley, manuscript in preparation). Several genera are needed to accommodate the component groups; two of these genera,

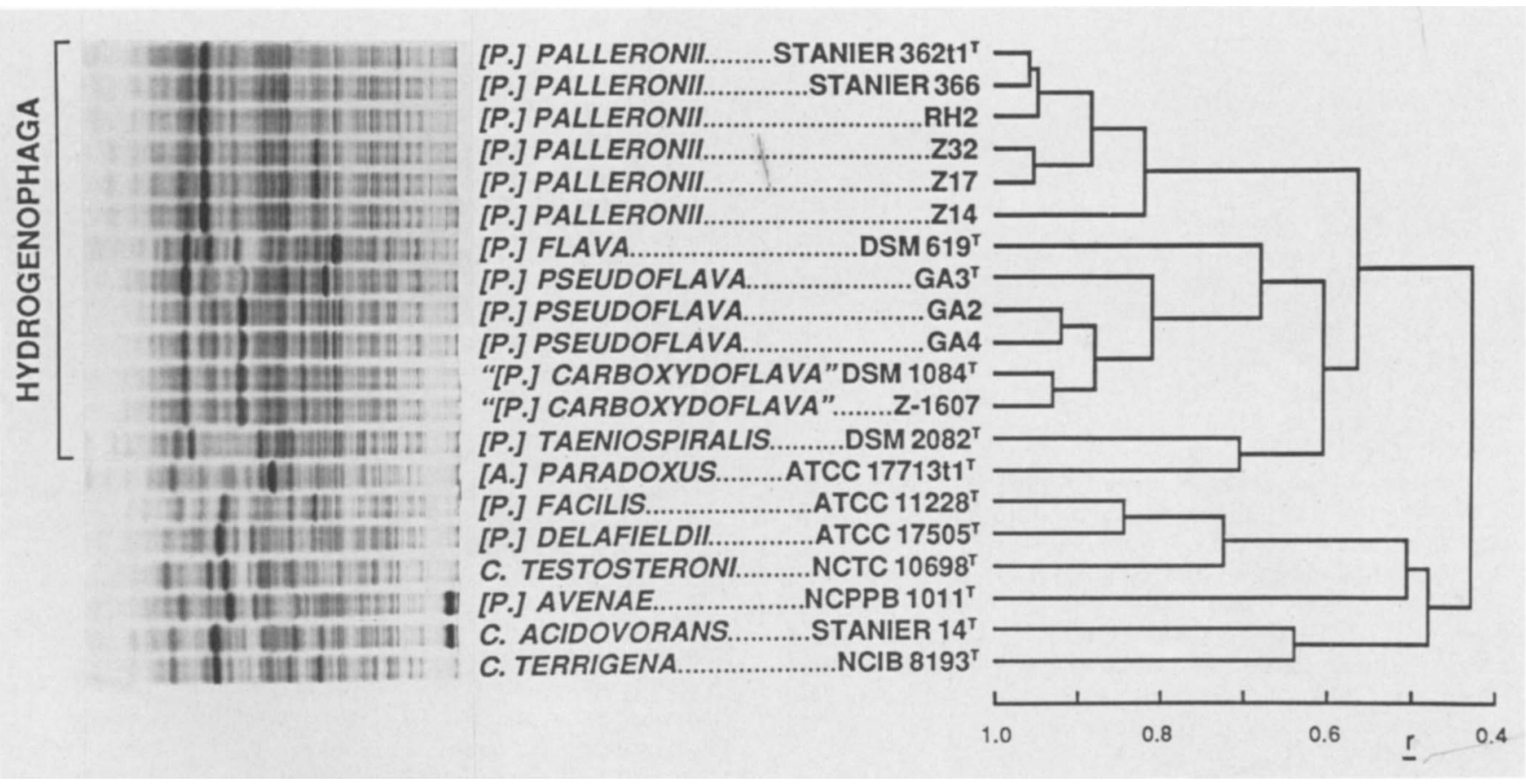

FIG. 4. Normalized sodium dodecyl sulfate-polyacrylamide gel electrophoretic patterns of representative strains of Hydrogenophaga species ([Pseudomonas] flava, [Pseudomonas] pseudoflava, "[Pseudomonas] carboxydoflava," [Pseudomonas] palleronii, [Pseudomonas] taeniospiralis) and the type strains of some reference taxa. The data are presented in a correlation coefficient $r$ dendrogram as calculated by the unweighted average pair group method. Each branch of the dendrogram faces the corresponding electrophoretic trace in the photograph. For abbreviations see the legend to Fig. 1. 
TABLE 4. Cellular fatty acid compositions of [Pseudomonas] flava, [Pseudomonas] palleronii, [Pseudomonas] pseudoflava, "[Pseudomonas] carboxydoflava," [Pseudomonas] taeniospiralis, [Pseudomonas] facilis, [Pseudomonas $]$ delafieldii, [Pseudomonas] avenae, Comamonas terrigena, Comamonas acidovorans, Comamonas testosteroni, [Alcaligenes] paradoxus, [Alcaligenes] latus, Rhodocyclus gelatinosus, and "[Pseudomonas] gazotropha"

\begin{tabular}{|c|c|c|c|c|c|c|c|c|c|c|c|c|c|c|c|}
\hline \multirow[b]{2}{*}{ Fatty acid } & \multicolumn{15}{|c|}{$\%$ of total in: } \\
\hline & $\begin{array}{c}\text { [Pseudo- } \\
\text { monas }] \\
\text { flava } \\
(1)^{a}\end{array}$ & $\begin{array}{c}\text { [Pseudo- } \\
\text { monas] } \\
\text { palleronii } \\
(7)\end{array}$ & $\begin{array}{l}\text { [Pseudo- } \\
\text { monas] } \\
\text { pseudo- } \\
\text { flava } \\
\text { (3) }\end{array}$ & $\begin{array}{c}\text { "[Pseudo- } \\
\text { monas }] \\
\text { carboxy- } \\
\text { doflava" } \\
(1)\end{array}$ & $\begin{array}{l}{[\text { Pseudo- }} \\
\text { monas }] \\
\text { taenio- } \\
\text { spiralis } \\
\quad(1)\end{array}$ & $\begin{array}{c}\text { [Pseudo- } \\
\text { monas }] \\
\text { facilis } \\
\quad(1)\end{array}$ & $\begin{array}{l}\text { [Pseudo- } \\
\text { monas] } \\
\text { delafieldii } \\
\quad(1)\end{array}$ & $\begin{array}{c}\text { [Pseudo- } \\
\text { monas] } \\
\text { avenae } \\
(1)\end{array}$ & $\begin{array}{l}\text { Comamo- } \\
\text { nas terri- } \\
\text { gena } \\
(4)\end{array}$ & $\begin{array}{c}\text { Comamo- } \\
\text { nas aci- } \\
\text { dovorans } \\
\text { (3) }\end{array}$ & $\begin{array}{c}\text { Comamo- } \\
\text { nas test- } \\
\text { osteroni } \\
\quad(3)\end{array}$ & $\begin{array}{c}{[\text { Alcali- }} \\
\text { genes }] \\
\text { paradoxus } \\
(3)\end{array}$ & $\begin{array}{c}\text { [Alcali- } \\
\text { genes }] \\
\text { latus } \\
(1)\end{array}$ & $\begin{array}{l}\text { [Rhodo- } \\
\text { cyclus] } \\
\text { gelatino- } \\
\text { sus } \\
\text { (1) }\end{array}$ & $\begin{array}{l}\text { "[Pseudo- } \\
\text { monas }] \\
\text { gazotro- } \\
\text { pha" (1) }\end{array}$ \\
\hline $2: 0^{b}$ & 0.2 & $0.0-\operatorname{tr}^{c}$ & $\operatorname{tr}$ & $\operatorname{tr}$ & 1.4 & 2.7 & 2.7 & 2.3 & $2.7-6.1$ & $2.6-3.4$ & $3.6-6.5$ & $2.7-3.0$ & 1.1 & 3.7 & 1.8 \\
\hline 4:0 & 2.8 & $0.2-0.4$ & $4.5-4.7$ & 3.3 & 3.1 & 2.7 & 4.1 & 2.4 & $3.0-3.9$ & $0.7-1.1$ & $0.5-0.6$ & $0.6-1.0$ & 2.3 & 4.3 & 3.2 \\
\hline $5: 1$ & $\operatorname{tr}$ & $0.1-3.1$ & $0.1-0.4$ & $\operatorname{tr}$ & 0.2 & & $\operatorname{tr}$ & & & & $\operatorname{tr}$ & $0.1-0.7$ & & 0.2 & $\operatorname{tr}$ \\
\hline $5: 0$ & 0.4 & $0.2-5.1$ & $0.6-0.7$ & 0.2 & 2.7 & 0.3 & 0.4 & 0.3 & $0.8-1.0$ & $0.3-1.1$ & $0.2-0.6$ & $0.1-1.9$ & $\operatorname{tr}$ & 0.4 & $\mathrm{tr}$ \\
\hline $6: 1$ & 51.7 & $25.3-34.4$ & $42.4-49.8$ & 45.0 & 43.1 & 42.4 & 39.5 & 41.6 & $37.5-41.5$ & $30.2-35.4$ & $22.2-33.5$ & $32.2-33.4$ & 35.3 & 38.7 & 50.3 \\
\hline $6: 0$ & 19.4 & $16.3-27.2$ & $23.1-25.9$ & 21.3 & 27.1 & 24.8 & 24.9 & 29.0 & $20.4-24.9$ & $23.9-28.3$ & $14.4-24.3$ & $20.7-26.5$ & 19.8 & 20.3 & 32.2 \\
\hline $7: 1$ & $\operatorname{tr}$ & $0.0-0.7$ & $\operatorname{tr}$ & $\operatorname{tr}$ & 0.7 & & $\operatorname{tr}$ & & $\operatorname{tr}$ & $\operatorname{tr}$ & & $\operatorname{tr}$ & & 0.2 & $\operatorname{tr}$ \\
\hline $7: 0$ & 1.3 & $0.2-7.1$ & $0.6-0.8$ & 0.3 & 0.7 & 0.2 & 0.2 & 0.2 & $0.2-0.4$ & $0.1-0.6$ & $\operatorname{tr}-6.8$ & $0.2-0.9$ & & 0.2 & tr \\
\hline $9-18: 1^{d}$ & 0.4 & $0.1-0.2$ & $0.2-0.7$ & 0.2 & 0.7 & 0.7 & 0.5 & 0.5 & $0.4-0.5$ & $0.4-0.6$ & $0.0-0.8$ & $0.6-0.8$ & 0.9 & 0.6 & \\
\hline $11-18: 1^{e}$ & 13.3 & $13.5-23.3$ & $7.8-9.4$ & 7.2 & 9.6 & 18.0 & 20.3 & 15.9 & $11.6-14.4$ & $14.7-16.6$ & $12.4-16.1$ & $12.3-20.1$ & 15.5 & 15.5 & 2.0 \\
\hline $8: 0$ & 1.5 & $0.2-0.5$ & $0.6-0.7$ & 0.7 & 0.3 & 0.2 & 0.3 & 0.3 & $\operatorname{tr}$ & $0.2-0.5$ & $0.2-0.8$ & $0.3-0.5$ & 2.7 & 0.2 & 0.2 \\
\hline $\begin{array}{l}7: \text { cyc } \\
9: \text { cyc }\end{array}$ & $\operatorname{tr}$ & $\begin{array}{c}12.9-21.1 \\
\mathrm{tr}\end{array}$ & $1.9-2.5$ & 2.4 & 5.3 & 0.2 & 0.4 & 0.2 & $1.2-4.8$ & $\begin{array}{c}9.0-14.5 \\
\operatorname{tr}\end{array}$ & $\underset{\text { tr }}{1.5-15.2}$ & $3.7-6.0$ & $\mathrm{tr}$ & 0.2 & 1.7 \\
\hline$-\mathrm{OH}-8: 0$ & 1.2 & $1.9-5.6$ & $1.0-1.5$ & 1.2 & 2.7 & 1.6 & 1.2 & & & $2.0-2.3$ & & $1.9-2.3$ & & & \\
\hline$-\mathrm{OH}-10: 0$ & 2.9 & & $1.1-4.1$ & 6.3 & & 4.4 & 4.5 & 5.8 & $7.4-9.0$ & $4.9-6.7$ & $7.8-17.3$ & $4.8-5.6$ & 7.2 & 7.4 & 5.6 \\
\hline -OH-18:0 & & & $\operatorname{tr}$ & & & & & & & & & & & & \\
\hline 2-OH-14:0 & & & & & & & & & & & $0.3-0.8$ & 3.0 & & & \\
\hline -OH-16:0 & & & & $\operatorname{tr}$ & & & & & & & $3.9-6.9$ & & & & \\
\hline$-\mathrm{OH}-18: 0$ & & & & & & & & & & & $0.2-1.7$ & & & & \\
\hline
\end{tabular}

The numbers in parentheses are the numbers of strains investigated; the type strain was included for each taxon.

Number of carbon atoms: number of double bonds.

Range among strains. tr, Less than $0.1 \%$.

Oleic acid.

e cis-Vaccenic acid. 


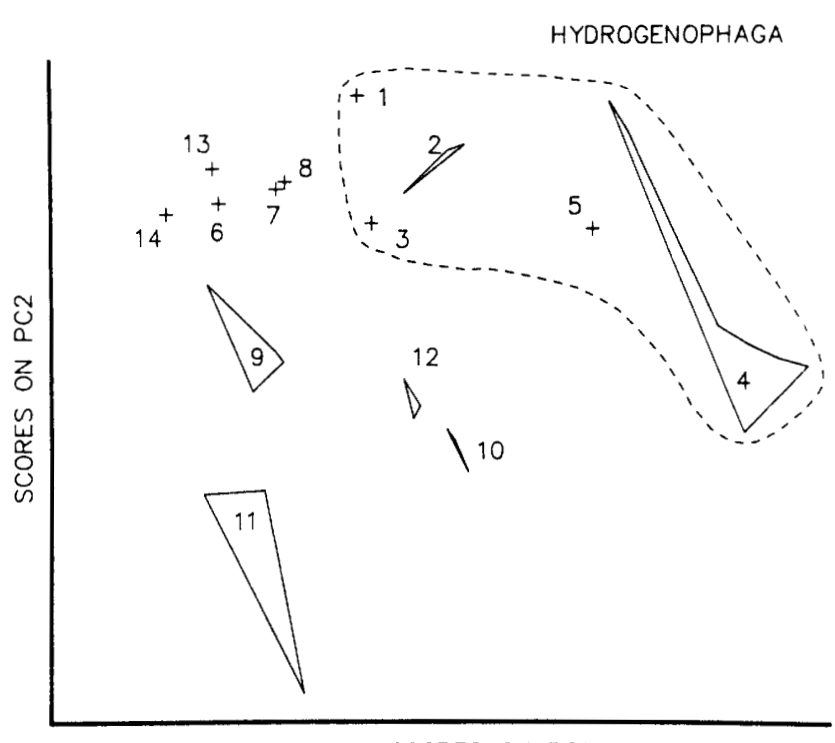

SCORES ON PC1

FIG. 5. Score plot of species on the basis of cellular fatty acid data. PC, principal component. Species: 1, [Pseudomonas] flava; 2, [Pseudomonas] pseudoflava; species 3, "[Pseudomonas] carboxydoflava"; 4, [Pseudomonas] palleronii; 5, [Pseudomonas] taeniospiralis; 6, [Pseudomonas $]$ avenae; 7, [Pseudomonas $]$ delafieldii; 8 , [Pseudomonas] facilis; 9, Comamonas terrigena; 10, Comamonas acidovorans; 11 , Comamonas testosteroni; 12 , [Alcaligenes] paradoxus; 13, [Alcaligenes] latus; and 14, [Rhodocyclus] gelatinosus.

Xylophilus (44) and Comamonas (16, 42), exist already. Inclusion of our five species in the genus Xylophilus is ruled out because of too many phenotypic differences (44). Transfer to the genus Comamonas is not acceptable either. Tamaoka et al. (42) proposed emendation of the genus Comamonas by including [Pseudomonas] acidovorans and [Pseudomonas] testosteroni in this genus. This proposal was based on a combination of data from several techniques, although no other taxa belonging to the acidovorans rRNA complex were included. Our DNA:rRNA hybridization data show that Comamonas acidovorans and Comamonas testosteroni do not belong to the Comamonas terrigena rRNA subbranch, but are located at the branching level, together with all other taxa in the acidovorans rRNA complex. This shows that a genus can consist of one or more rRNA subbranches, but the acidovorans rRNA complex is too heterogeneous to be included in one genus. For taxonomic conclusions DNA:rRNA hybridization data should be evaluated in combination with the results from other techniques (44). There are important genotypic and immunotypic differences between the members of the genus Comamonas and the five yellow-pigmented hydrogen-oxidizing species (Fig. 1 and Table 3). Moreover, phenotypic differentiation of the species belonging to the genus Comamonas is clearly possible (Table 5), although in some features [Pseudomonas] palleronii is aberrant from its four neighbors. The separate position of the five yellow-pigmented hydrogen-oxidizing species should be reflected by creation of a new genus. We propose to name the new genus Hydrogenophaga. Features differentiating the genus Hydrogenophaga from the other hydrogen-oxidizing taxa of the acidovorans rRNA complex and from the genus Comamonas are given in Table 5.

The internal taxonomy of the genus Hydrogenophaga was

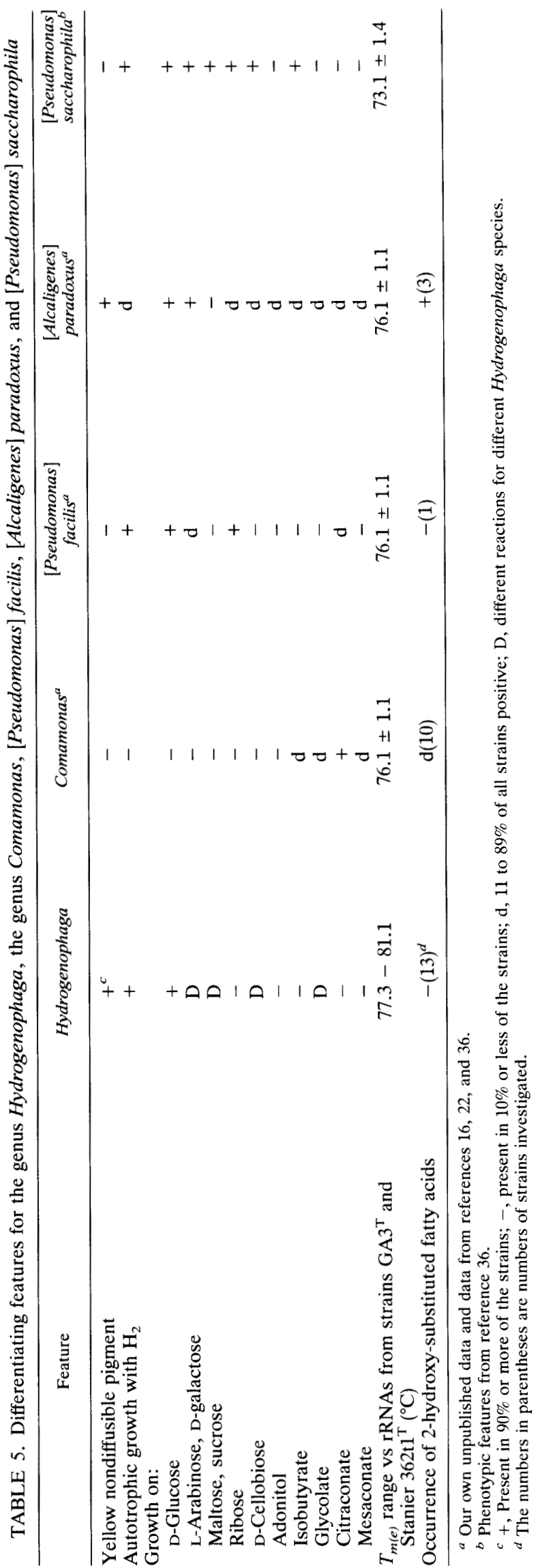


studied by using several suitable techniques. "[Pseudomonas] carboxydoflava" and [Pseudomonas] pseudoflava strains produce very similar protein electropherograms (Fig. 4 ) and have very similar fatty acid compositions (Table 4 and Fig. 5) and phenotypic features $\left(\mathrm{S}_{\mathrm{G}}\right.$ value, $82.3 \%$ ) (Fig. 3). A DNA-binding level of at least $79 \%$ (Fig. 2 ) and $T_{m(e)}$ values for hybridizations between "[Pseudomonas] carboxydoflava" DNA and rRNA of [Pseudomonas] pseudoflava $\mathrm{GA} 3^{\mathrm{T}}$ of 79.2 to $80.8^{\circ} \mathrm{C}$ (Table 2) justify the fusion of these two taxa into one species, Hydrogenophaga pseudoflava. The ability of "[Pseudomonas] carboxydoflava" to grow at the expense of carbon monoxide (33) should not be an argument for maintaining it as a separate species. Plasmids have been found in "[Pseudomonas] carboxydoflava" DSM $1084^{\mathrm{T}}$, and carbon monoxide oxidation has been determined to be a plasmid-encoded, and thus not stable, trait in other gram-negative bacteria (26).

Our DNA:DNA hybridization results indicate a close relationship among [Pseudomonas] flava, [Pseudomonas] pseudoflava, and "[Pseudomonas] carboxydoflava" (Fig. 2) (degree of binding, 48 to 62\%). The protein electrophoretic pattern of [Pseudomonas] flava resembles the patterns of the [Pseudomonas] pseudoflava strains, but it is clearly different from them in the central part of the gel (Fig. 4). On the other hand, the fatty acid compositions did not reveal any significant differences between [Pseudomonas] flava and [Pseudomonas] pseudoflava. As Fig. 5 shows, these species form a uniform cluster without any visible subgrouping, but distinctly separated from the cluster formed by [Pseudomonas] palleronii and [Pseudomonas] taeniospiralis. However, because of the considerable phenotypic and other differences with [Pseudomonas] flava, Auling et al. (4) created [Pseudomonas] pseudoflava as a separate species. This is also reflected in the results of our phenotypic analysis (Fig. 3 ), and we therefore prefer to maintain the two taxa as separate species, Hydrogenophaga flava and Hydrogenophaga pseudoflava.

Al] [Pseudomonas] palleronii strains form a homogeneous and separate group as determined by sodium dodecyl sulfate-polyacrylamide gel electrophoresis (Fig. 4), as well as by phenotypic analyses (Fig. 3), numerical analysis of fatty acid patterns (Fig. 5), and DNA:DNA hybridization (Fig. 2). These strains are transferred to the genus Hydrogenophaga as a separate species, Hydrogenophaga palleronii. Auling et al. (2) also reported very low DNA:DNA hybridization values between [Pseudomonas] palleronii and both [Pseudomonas] pseudoflava and [Pseudomonas] flava (degrees of binding, 25 and $34 \%$, respectively).

[Pseudomonas] taeniospiralis, containing only one strain, occupies gel electrophoretically (Fig. 4), genotypically (Fig. 2), and phenotypically (Fig. 3) a separate position among the yellow-pigmented hydrogen-oxidizing [Pseudomonas] species. From the numerical analysis of fatty acid patterns (Fig. 5) a closer relationship with [Pseudomonas] palleronii can be presumed, but this could not be confirmed by DNA:DNA hybridizations (Fig. 2). [Pseudomonas] taeniospiralis is transferred to the genus Hydrogenophaga as Hydrogenophaga taeniospiralis. Differentiating features for the four Hydrogenophaga species are shown in Table 6.

"[Pseudomonas] gazotropha" was included in this study because its facultatively lithoautotrophic growth at the expense of hydrogen or carbon monoxide (48) could indicate a closer relationship to [Pseudomonas] pseudoflava. Our results (Tables 2 and 3) prove that "[Pseudomonas] gazotropha" is a member of rRNA superfamily III, but its exact position within this group is still unknown. The presence of hydroxyputrescine also indicates that it belongs in rRNA superfamily III (5). It is not related to [Pseudomonas] pseudoflava and does not belong to the acidovorans rRNA complex. Furthermore, the fatty acid pattern of "[Pseudomonas] gazotropha" DSM $1085^{\mathrm{T}}$ does not contain oleic acid ( $\Delta 9-18: 1)$, which is present in all of the strains belonging to the acidovorans rRNA complex which we tested.

Description of Hydrogenophaga gen. nov. Hydrogenophaga (Hy.dro.ge.no' pha.ga. Gr. n. hydoor, water; Gr. n. gennao, to create; M.L. hydrogenum, hydrogen, that which produces water; Gr. v. phagein, to eat; M.L. fem. n. Hydrogenophaga, eater of hydrogen). Cells are straight to slightly curved rods ( 0.3 to 0.6 by 0.6 to $5.5 \mu \mathrm{m})$; they occur singly or in pairs. Motile by means of one, rarely two, polar to subpolar flagella. Gram negative. Oxidase positive. Catalase variable. A nondiffusible yellow pigment is produced. Aerobic. Chemoorganotrophic or chemolithoautotrophic, using the oxidation of hydrogen as an energy source. Oxidative carbohydrate metabolism with oxygen as a terminal electron acceptor or heterotrophic denitrification of nitrate (by $\mathrm{Hy}$ drogenophaga pseudoflava and Hydrogenophaga taeniospiralis). Cells grow well on media containing organic acids, amino acids, or peptone, but are less versatile in the use of carbohydrates. A cyclopropane-substituted fatty acid (17: cyc) is present; 3-hydroxy-octanoic acid (3-OH-8:0) is present alone or together with 3-hydroxy-decanoic acid (3-OH-10:0). 2-Hydroxy-substituted fatty acids are absent. Ubiquinone Q-8 is present as the main quinone. 2-Hydroxyputrescine and putrescine are present in roughly equimolar concentrations either exclusively or as the dominant polyamine compounds. The mean $\mathrm{G}+\mathrm{C}$ content of the DNA ranges from 65 to $69 \mathrm{~mol} \%$. In DNA:rRNA hybridizations $T_{m(e)}$ values of 77.3 to $81.1^{\circ} \mathrm{C}$ are obtained versus rRNA from Hydrogenophaga pseudoflava $\mathrm{GA} 3^{\mathrm{T}}$ or Hydrogenophaga palleronii Stanier $362 \mathrm{t1}^{\mathrm{T}}$. The genus Hydrogenophaga belongs to the acidovorans rRNA complex. It is equidistantly related to the following other taxa in this complex: the genera Comamonas and Xylophilus and the generically misnamed species [Pseudomonas] facilis, [Pseudomonas] delafieldii, [Pseudomonas] avenae, and [Alcaligenes] paradoxus. The type species is Hydrogenophaga flava (Niklewski 1910) comb. nov. This species grows slowly and easily loses its chemolithoautotrophic ability (4). Because of its high genotypic and protein electrophoretic similarity to the type species, Hydrogenophaga pseudoflava can be used as an alternative reference species for the genus.

Description of Hydrogenophaga flava (Niklewski 1910) comb. nov. The description of Hydrogenophaga flava (fla'va. L. fem. adj. flava, yellow) is the same as that for the genus. The ability to grow lithoautotrophically at the expense of hydrogen is easily lost (4). Aragno et al. (1) reported the presence of pili spread over the total cell surface. Morphological, biochemical, and nutritional features have been described by Davis et al. (8) and by Palleroni (36). Our findings, comprising more than 250 features, corroborate these data fairly well except for the following features (our results are indicated in parentheses): amylase (negative) and the use of the following substrates as sole carbon sourcesD-arabinose (positive), salicin (positive), levulinate (positive), L-isoleucine (positive), L-histidine (positive), butyrate (late [ 7 to 15 days]), amylamine (late), L-tartrate (negative), 2 -ketoglutarate (negative), and $L-\alpha$-alanine (negative). The hydrolysis of esculin and the urease reaction are positive. Hydrogenophaga flava was isolated from mud. The mean $\mathrm{G}+\mathrm{C}$ content of the DNA is $67 \mathrm{~mol} \%$. The monotype strain is strain DSM $619(=$ LMG $2185=$ CCUG $1658=$ ATCC 
TABLE 6. Differentiation among the four Hydrogenophaga species

\begin{tabular}{|c|c|c|c|c|}
\hline Feature & $\begin{array}{c}\text { Hydro- } \\
\text { geno- } \\
\text { phaga } \\
\text { flava }\end{array}$ & $\begin{array}{l}\text { Hydro- } \\
\text { geno- } \\
\text { phaga } \\
\text { pallero- } \\
\text { nii }\end{array}$ & $\begin{array}{l}\text { Hydro- } \\
\text { geno- } \\
\text { phaga } \\
\text { pseudo- } \\
\text { flava }\end{array}$ & $\begin{array}{l}\text { Hydro- } \\
\text { geno- } \\
\text { phaga } \\
\text { taenio- } \\
\text { spiralis }\end{array}$ \\
\hline \multicolumn{5}{|l|}{ Growth on: } \\
\hline Glycolate & + & + & + & - \\
\hline $\begin{array}{l}\text { L-Arabinose, sucrose, D-galac- } \\
\text { tose, D-fructose, D-mannose, } \\
\text { mannitol, D-arabitol, sorbitol, } \\
\text { D-cellobiose, butylamine, eth- } \\
\text { anolamine }\end{array}$ & + & - & + & + \\
\hline Maltose, D-turanose, L-histidine & + & - & + & - \\
\hline L-Fucose & + & - & - & + \\
\hline Azelate & - & + & + & + \\
\hline D-Xylose, DL-5-aminovalerate & - & - & + & + \\
\hline Lactose & - & - & + & - \\
\hline DL-3-Aminobutyrate & - & - & - & + \\
\hline Denitrification & - & - & + & + \\
\hline Reduction of nitrate & + & - & + & + \\
\hline Reduction of nitrite & - & - & + & + \\
\hline $\begin{array}{l}\text { Presence of 3-hydroxy-decanoic } \\
\text { acid }\end{array}$ & + & - & + & - \\
\hline
\end{tabular}

33667). This strain is the neotype strain proposed by Klyuver and Manten (25) to replace the original [Pseudomonas] flava type strain of Niklewski (32), which has been lost.

Description of Hydrogenophaga palleronii. (Davis, Stanier, Doudoroff, and Mandel 1970) comb. nov. The description of Hydrogenophaga palleronii (pal.le.ro'ni.i. M.L. gen. n. palleronii, of Palleroni, named after N. J. Palleroni, who first isolated the type strain) is the same as that for the genus. Two strains, including the type strain, have been reported to bear pili at the polar caps of the cells (1). Biochemical and nutritional features have been described by Davis et al. (8) and by Palleroni (36). The findings of these authors are in good agreement with our own extensive findings, except for the auxanographic features listed below. All of the strains tested use isovalerate and sebacate as sole carbon sources. Only some strains (listed in parentheses) use the following substrates as sole carbon sources: $\mathrm{L}-\alpha$-alanine, L-leucine, and L-phenylalanine (Stanier $362 \mathrm{t}^{\mathrm{T}}, \mathrm{RH} 2, \mathrm{Z14}, \mathrm{Z17}$, and Z32); pimelate (Stanier $362 \mathrm{t1}^{\mathrm{T}}$, Stanier $366, \mathrm{RH} 2, \mathrm{Z} 32$, and Z17); DL-norleucine (Stanier $362 \mathrm{t}^{\mathrm{T}}, \mathrm{Z14}, \mathrm{Z17}$, and Z32); L-norleucine and $\mathrm{D}$ - $\alpha$-alanine (Stanier $362 \mathrm{t1}^{\mathrm{T}}, \mathrm{RH} 2$, and Z32); L-tyrosine and L-trypthophan ( $\mathrm{RH} 2, \mathrm{Z14}$, and $\mathrm{Z17}$ ); $n$-valerate (Stanier $362 \mathrm{t} 1^{\mathrm{T}}$, Stanier 366 , and RH2); terephthalate (Stanier $362 \mathrm{t1}^{\mathrm{T}}$ and Stanier 366); L-isoleucine (Stanier $362 \mathrm{t}^{\mathrm{T}}$ and Z32); propionate (Stanier 366 and RH2); and itaconate $\left(\right.$ Stanier $362 \mathrm{t1}^{\mathrm{T}}$ ). None of the strains tested use the following organic acids as sole carbon sources: acetate, L-tartrate, 2-ketoglutarate, aconitate, and citrate. For four of the seven strains tested, weak production of acid in oxidative-fermentative medium containing D-glucose occurs; the type strain does not produce acid, in agreement with the report by Auling et al. (4). Hydrogenophaga palleronii strains were isolated from water enriched for hydrogen bacteria. The mean $\mathrm{G}+\mathrm{C}$ content of the DNA ranges from 67 to $68 \mathrm{~mol} \%$. The type strain is strain Stanier $362 \mathrm{tl}$ (= LMG $2366 \mathrm{t} 1=$ CCUG $20334=$ ATCC 17724). Its characteristics are the same as those listed above for the species, and the mean $\mathrm{G}+\mathrm{C}$ content of its DNA is $67 \mathrm{~mol} \%$.

Description of Hydrogenophaga pseudoflava (Auling, Reh, Lee, and Schlegel 1978) comb. nov. The description of
Hydrogenophaga pseudoflava (pseu.do.fla'va. Gr. adj. pseudes, false; L. fem. adj. flava, yellow; M. L. fem. adj. pseudoflava, not the true [Pseudomonas] flava) is the same as that for the genus. Some strains of this species (originally described as "[Pseudomonas] carboxydoflava") are facultative autotrophs, growing at the expense of carbon monoxide oxidation (33). Aragno et al. (1) reported the presence of pili over the total cell surface for two strains, including the type strain. Since this species includes strains of both the former species [Pseudomonas] pseudoflava and the former species "[Pseudomonas] carboxydoflava," we provide a new description for Hydrogenophaga pseudoflava based on our own results, which are generally in good agreement with the original species descriptions $(4,48)$. Nutritional and enzymatic features are listed in Table 7 . The following biochemical and physiological characteristics are present in all $\mathrm{Hy}$ drogenophaga pseudoflava strains: growth at 30 and $37^{\circ} \mathrm{C}$, growth in the presence of $0.5 \% \mathrm{NaCl}$, hydrolysis of Tween 80 and esculin, reduction of nitrate and nitrite, denitrification, and $\beta$-galactosidase. The following features are lacking in all Hydrogenophaga pseudoflava strains: catalase, hemolysis, resistance to penicillin (10 $\mu \mathrm{g}$ per disk), growth on Drigalski-Conradi agar at $30^{\circ} \mathrm{C}$, growth at $42^{\circ} \mathrm{C}$, growth in the presence of $1.5,3,4.5$, or $6.5 \% \mathrm{NaCl}$, production of acid in $10 \%$ lactose, triple sugar iron medium, and oxidative-fermentative medium containing D-glucose, D-fructose, D-xylose, maltose, or adonitol, fluorescence, growth on cetrimide, production of $\mathrm{H}_{2} \mathrm{~S}$ in triple sugar iron medium, amylase, lysine and ornithine decarboxylase, arginine dihydrolase, urease, and hydrolysis of gelatin. Hydrolysis of DNA and acetamide and production of acid from indole are absent in all strains except the type strain, which was not tested. Recently, Jenni et al. (21) reported nitrogen fixation for a strain (strain NEU 2226) which they assigned to [Pseudomonas] pseudoflava, although this feature could not be detected in strain $\mathrm{GA} 3^{\mathrm{T}}$. Hydrogenophaga pseudoflava was isolated from soil, mud, and water by enrichment for hydrogen bacteria $(4,33)$. The mean $\mathrm{G}+\mathrm{C}$ content of the DNA is 66 to 69 mol\%. The type strain is strain GA3 (= LMG $5945=$ CCUG $13799=$ ATCC 33668). Its characteristics are the same as those listed above for the species, and the mean $\mathrm{G}+\mathrm{C}$ content of its DNA is $66 \mathrm{~mol} \%$.

Description of Hydrogenophaga taeniospiralis (Lalucat, Parés, and Schlegel 1982) comb. nov. The description of Hydrogenophaga taeniospiralis (tae.ni.o.spi.ra'lis. Gr. n. taenia, ribbon; L. adj. spiralis, coiled; M.L. adj. taeniospiralis, ribbon coiled, named after Caedibacter taeniospiralis, an organism also containing $\mathrm{R}$ bodies) is the same as that for the genus. The original description by Lalucat et al. (28) was verified. This description was found to be in good agreement with our own results, except for the following features (our results are indicated in parentheses): reduction of nitrite (positive), hydrolysis of esculin (positive), urease (weak), catalase (negative), growth at $37^{\circ} \mathrm{C}$ (negative), and use of the following substrates as sole carbon sources-butyrate (positive), trehalose (negative), and L-lysine (negative). Additions to the original description are presented below. Nutritional and enzymological features are listed in Table 7. Hydrogenophaga taeniospiralis grows at $30^{\circ} \mathrm{C}$, hydrolyzes Tween 80 , and possesses $\beta$-galactosidase. The following features are lacking: growth at $42^{\circ} \mathrm{C}$, growth on DrigalskiConradi agar at $30^{\circ} \mathrm{C}$, growth in the presence of $0.5,1.5,3$, 4.5 , or $6.5 \% \mathrm{NaCl}$, resistance to penicillin $(10 \mu \mathrm{g}$ per disk), hemolysis, production of acid in oxidative-fermentative medium containing D-glucose, maltose, or adonitol, growth on cetrimide, lysine and ornithine decarboxylase, arginine di- 
TABLE 7. Nutritional and enzymatic features of Hydrogenophaga pseudofava and Hydrogenophaga taeniospiralis

\begin{tabular}{|c|c|c|}
\hline Feature & $\begin{array}{l}\text { Hydrogenophaga } \\
\text { pseudoflava } \\
\text { (5 strains) }\end{array}$ & $\begin{array}{l}\text { Hydrogenophaga } \\
\text { taeniospiralis } \\
\text { (1 strain) }\end{array}$ \\
\hline \multicolumn{3}{|l|}{ Carbon sources for growth ${ }^{a}$ : } \\
\hline $\begin{array}{l}\text { D-Turanose, maltose, lactose, trehalose, salicin, acetate, propionate, } n \text {-valerate, } \\
\text { glycolate, } \mathrm{L} \text { - } \alpha \text {-alanine, } \mathrm{L} \text {-serine, } \mathrm{L} \text {-lysine, } \mathrm{L} \text {-histidine, amylamine, benzylamine }\end{array}$ & $++^{b}$ & - \\
\hline L-Fucose, glutarate, 2-ketoglutarate, DL-3-aminobutyrate & - & + \\
\hline L-Isoleucine, diaminobutane & $\mathrm{GA}^{\mathrm{T}}$, GA4, DSM 1084, Z-1607 & + \\
\hline$m$-Hydroxybenzoate & $\mathrm{GA}^{\mathrm{T}}, \mathrm{GA} 2, \mathrm{GA} 4, \mathrm{DSM} 1084$ & - \\
\hline$n$-Caproate & $\mathrm{GA} 3^{\mathrm{T}}, \mathrm{GA} 2, \mathrm{GA} 4, \mathrm{Z}-1607$ & - \\
\hline L-Valine & $\mathrm{GA}^{\mathrm{T}}, \mathrm{GA} 2, \mathrm{DSM} 1084, \mathrm{Z}-1607$ & - \\
\hline L-Mandelate, inositol, L-aspartate & $\mathrm{GA} 3^{\mathrm{T}}, \mathrm{GA} 2, \mathrm{GA} 4$ & + \\
\hline D- $\alpha$-Alanine & $\mathrm{GA}^{\mathrm{T}}, \mathrm{GA} 2, \mathrm{GA} 4$ & - \\
\hline$p$-Hydroxybenzoate & $\mathrm{GA}^{\mathrm{T}}, \mathrm{GA} 2, \mathrm{DSM} 1084$ & - \\
\hline Spermine & $\mathrm{GA3}^{\mathrm{T}}, \mathrm{DSM} 1084, \mathrm{Z}-1607$ & + \\
\hline L-Threonine, isovalerate & $\mathrm{GA}^{\mathrm{T}}, \mathrm{DSM} 1084, \mathrm{Z}-1607$ & - \\
\hline L-Norleucine, DL-norvaline & $\mathrm{GA} 3^{\mathrm{T}}, \mathrm{GA} 2$ & - \\
\hline L-Arginine & $\mathrm{GA} 3^{\mathrm{T}}, \mathrm{GA} 4$ & + \\
\hline DL-2-Aminobutyrate & $\mathrm{GA}^{\mathrm{T}}, \mathrm{GA} 4$ & - \\
\hline D-Lyxose & DSM 1084, Z-1607 & - \\
\hline Citrate & GA4, DSM 1084 & - \\
\hline L-Rhamnose & GA2 & + \\
\hline L-Tartrate & GA2 & - \\
\hline DL-Norleucine & GA4 & - \\
\hline \multicolumn{3}{|l|}{ Hydrolysis of ${ }^{c}$ : } \\
\hline 2-Naphthylphosphate (pH 8.5), 2-naphthyl- $\alpha$-D-glucopyranoside & GA2, GA4, DSM 1084 & - \\
\hline 6-Bromo-2-naphthyl- $\beta$-D-glucopyranoside & $\mathrm{GA} 2, \mathrm{GA} 4$ & + \\
\hline 2-Naphthylmyristate & GA2 & - \\
\hline
\end{tabular}

${ }^{a}$ All Hydrogenophaga pseudoflava strains and Hydrogenophaga taeniospiralis DSM $2082^{\mathrm{T}}$ use the following substrates as sole carbon sources: D-xylose, L-arabinose, D-galactose, D-glucose, D-fructose, D-mannose, sucrose, D-cellobiose, glycerol, sorbitol, D-arabitol, mannitol, gluconate, pyruvate, butyrate, succinate, fumarate, suberate, azelate, levulinate, sebacate, DL-lactate, DL-glycerate, DL-3-hydroxybutyrate, D-malate, L-malate, L-leucine, L-phenylalanine, L-tyrosine, L-tryptophan, L-glutamate, L-ornithine, L-proline, DL-4-aminobutyrate, DL-5-aminovalerate, butylamine, and ethanolamine. All strains use DL-lactate as a sole carbon source in the presence of L-methionine. The following substrates are not used by either species: D-ribose, L-xylose, methyl- $\beta$-D-xyloside, D-fucose, D-arabinose, L-sorbose, methyl- $\alpha$-D-mannoside, methyl- $\alpha$-D-glucoside, D-tagatose, D-melibiose, D-melezitose, D-raffinose, $\beta$-gentiobiose, amygdalin, arbutin, esculin, inulin, starch, glycogen, erythritol, adonitol, dulcitol, xylitol, L-arabitol, 2-ketogluconate, 5-ketogluconate, $N$-acetylglucosamine, isobutyrate, isovalerate, heptanoate, caprylate, pelargonate, caprate, oxalate, malonate, maleate, adipate, pimelate, D-tartrate, meso-tartrate, citraconate, itaconate, mesaconate, aconitate, phenylacetate, benzoate, $o$-hydroxybenzoate, D-mandelate, phthalate, isophthalate, terephthalate, glycine, L-cysteine, L-methionine, D-tryptophan, trigonellin, L-citrulline, DL-kynurenine, betaine, creatine, $\beta$-alanine, 2-aminobenzoate, 3-aminobenzoate, 4-aminobenzoate, urea, acetamide, sarcosine, ethylamine, histamine, tryptamine, and glucosamine.

${ }^{b}+$, Present in all strains tested; - , absent in all strains tested. For features present in only some strains, those strains are listed.

${ }^{c}$ API ZYM galleries were used. All Hydrogenophaga pseudoflava strains and Hydrogenophaga taeniospiralis DSM 2082 ${ }^{\mathrm{T}}$ hydrolyze 2-naphthylcaprylate, 2-naphthylbutyrate, and L-leucyl-2-naphthylamide. The following substrates are not hydrolyzed by either species: L-cystyl-2-naphthylamide, L-valyl-2naphthylamide, $N$-benzoyl-DL-arginine-2-naphthylamide, $N$-glutaryl-phenylalanine-2-naphthylamide, 2-naphthylphosphate (pH 5.4), 6-bromo-2-phosphodiamide3-naphthoic acid-2-methoxyanilide (= naphthol-AS-BI-phosphodiamide), 6-bromo-2-naphthyl- $\alpha$-D-galactopyranoside, 2-naphthyl- $\beta$-D-galactopyranoside, 6bromo-2-hydroxy-3-naphthoic acid-2-methoxyanilide-- $\beta$-D-glucuronate (= naphthol-AS-BI- $\beta$-D-glucuronate), 1-naphthyl- $N$-acetyl- $\beta$-D-glucosaminide, 6 -bromo2-naphthyl- $\alpha$-D-mannopyranoside, and 2-naphthyl- $\alpha$-L-fucopyranoside.

hydrolase, and hydrolysis of acetamide. Hydrogenophaga taeniospiralis was isolated from soil near Barcelona, Spain. The mean $\mathrm{G}+\mathrm{C}$ content of the DNA is $65 \mathrm{~mol} \%$. The monotype strain is strain DSM 2082 (= LMG $7170=$ CCUG 15921).

\section{ACKNOWLEDGMENTS}

We are indebted to API System S. A., La Balme-les-Grottes, Montalieu-Vercieu, France, for supplying API galleries and to G. A. Zavarzin, Moscow, USSR, for supplying strains. E.F. is obliged to Ann Börjesson and Marie Blomqvist for excellent technical assistance.

J.D.L. and K.K. are indebted to the Nationaal Fonds voor Geneeskundig Onderzoek, Belgium, for research and personnel grants. G.A. acknowledges support by a grant from the German Collection of Microorganisms and Cell Cultures, Ltd., Braunschweig, Federal Republic of Germany. A.W. and M. Goor are indebted to the Nationaal Fonds voor Wetenschappelijk Onderzoek, Belgium, for positions as Research Assistants. B.P. is indebted to the Instituut tot Aanmoediging van het Wetenschappelijk Onderzoek in Nijverheid en Landbouw, Belgium, for a scholarship. Part of this research was carried out in the framework of contract BAP0138-B of the Biotechnology Action Program of the Commission of the European Communities.

\section{LITERATURE CITED}

1. Aragno, M., A. Walther-Mauruschat, F. Mayer, and H. G. Schlegel. 1977. Micromorphology of Gram-negative hydrogen bacteria. I. Cell morphology and flagellation. Arch. Microbiol. 114:93-100.

2. Auling, G., M. Dittbrenner, M. Maarzahl, T. Nokhal, and M. Reh. 1980. Deoxyribonucleic acid relationships among hydrogen-oxidizing strains of the genera Pseudomonas, Alcaligenes, and Paracoccus. Int. J. Syst. Bacteriol. 30:123-128.

3. Auling, G., A. Probst, and R. M. Kroppenstedt. 1986. Chemoand molecular taxonomy of $\mathrm{D}(-)$-tartrate-utilizing pseudomonads. Syst. Appl. Microbiol. 8:114-120.

4. Auling, G., M. Reh, C. M. Lee, and H. G. Schlegel. 1978. Pseudomonas pseudoflava, a new species of hydrogen-oxidizing bacteria: its differentiation from Pseudomonas flava and other yellow-pigmented, gram-negative hydrogen-oxidizing species. Int. J. Syst. Bacteriol. 28:82-95.

5. Busse, J., and G. Auling. 1989. Polyamine pattern as a chemo- 
taxonomic marker within the Proteobacteria. Syst. Appl. Microbiol. 11:1-8.

6. Byng, G. S., J. L. Johnson, R. J. Whitaker, R. L. Gherna, and R. A. Jensen. 1983. The evolutionary pattern of aromatic amino acid biosynthesis and the emerging phylogeny of pseudomonad bacteria. J. Mol. Evol. 19:272-282.

7. Davis, D. H., M. Doudoroff, R. Y. Stanier, and M. Mandel. 1969. Proposal to reject the genus Hydrogenomonas: taxonomic implications. Int. J. Syst. Bacteriol. 19:375-390.

8. Davis, D. H., R. Y. Stanier, M. Doudoroff, and M. Mandel. 1970. Taxonomic studies on some Gram negative polarly flagellated "hydrogen bacteria" and related species. Arch. Mikrobiol. 70:1-13.

9. De Ley, J. 1970. Reexamination of the association between melting point, buoyant density, and chemical base composition of deoxyribonucleic acid. J. Bacteriol. 101:738-754.

10. De Ley, J. 1978. Modern molecular methods in bacterial taxonomy: evaluation, application, prospects, p. 347-357. In Proceedings of the 4th International Conference of Plant Pathogenic Bacteria, vol. 1. Gibert-Clarey, Tours, France.

11. De Ley, J., H. Cattoir, and A. Reynaerts. 1970. The quantitative measurement of DNA hybridization from renaturation rates. Eur. J. Biochem. 12:133-142.

12. De Ley, J., and J. De Smedt. 1975. Improvements of the membrane filter method for DNA:rRNA hybridization. Antonie van Leeuwenhoek J. Microbiol. Serol. 41:287-307.

13. De Ley, J., and J. Van Muylem. 1963. Some applications of deoxyribonucleic acid base composition in bacterial taxonomy. Antonie van Leeuwenhoek J. Microbiol. Serol. 29:344-358.

14. De Vos, P., and J. De Ley. 1983. Intra- and intergeneric similarities of Pseudomonas and Xanthomonas ribosomal ribonucleic acid cistrons. Int. J. Syst. Bacteriol. 33:487-509.

15. De Vos, P., M. Goor, M. Gillis, and J. De Ley. 1985. Ribosomal ribonucleic acid cistron similarities of phytopathogenic Pseudomonas species. Int. J. Syst. Bacteriol. 35:169-184.

16. De Vos, P., K. Kersters, E. Falsen, B. Pot, M. Gillis, P. Segers, and J. De Ley. 1985. Comamonas Davis and Park 1962 gen. nov. nom. rev. emend., and Comamonas terrigena Hugh $1962 \mathrm{sp}$. nov., nom. rev. Int. J. Syst. Bacteriol. 35:443-453.

17. Falsen, E. 1983. Immunodiffusion as an aid in routine identification of uncommon aerobic gram negative bacteria, p. 477-483. In $\mathrm{H}$. Leclerc (ed.), Gram negative bacteria of medical and public health importance: taxonomy-identification-applications. Les éditions de l'Institut National de la Santé et de la Recherche Médicale, Paris.

18. Jantzen, E., and K. Bryn. 1985. Whole-cell and lipopolysaccharide fatty acids and sugars of gram-negative bacteria, p. 145171. In M. Goodfellow and D. Minnikin (ed.), Chemical methods in bacterial systematics. Academic Press, Inc., New York.

19. Jantzen, E., K. Bryn, N. Hagen, T. Bergan, and K. Bфvre. 1978. Fatty acids and monosaccharides of Neisseriaceae in relation to established taxonomy. Natl. Inst. Public Health Ann. (Norway) 1:59-71.

20. Jantzen, E., O. M. Kvalheim, T. A. Hauge, N. Hagen, and K. Bovre. 1987. Grouping of bacteria by SIMCA pattern recognition on gas chromatographic lipid data: patterns among Moraxella and rod-shaped Neisseria. Syst. Appl. Microbiol. 9:142150.

21. Jenni, B., C. Isch, and M. Aragno. 1989. Nitrogen fixation by new strains of Pseudomonas pseudoflava and related bacteria. J. Gen. Microbiol. 135:461-467.

22. Kersters, K., and J. De Ley. 1984. Genus Alcaligenes Castellani and Chalmers 1919, p. 361-373. In N. R. Krieg and J. G. Holt (ed.), Bergey's manual of systematic bacteriology, vol. 1. The Williams \& Wilkins Co., Baltimore.

23. Kersters, K., K.-H. Hinz, A. Hertle, P. Segers, A. Lievens, O. Siegmann, and J. De Ley. 1984. Bordetella avium sp. nov., isolated from the respiratory tracts of turkeys and other birds. Int. J. Syst. Bacteriol. 34:56-70.

24. Kiredjian, M., B. Holmes, K. Kersters, I. Guilvout, and J. De Ley. 1986. Alcaligenes piechaudii, a new species from human clinical specimens and the environment. Int. J. Syst. Bacteriol. 36:282-287.

25. Kluyver, A. J., and A. Manten. 1942. Some observations on the metabolism of bacteria oxidizing molecular hydrogen. Antonie van Leeuwenhoek. J. Microbiol. Serol. 8:71-85.

26. Kraut, M., and O. Meyer. 1988. Plasmids in carboxydotrophic bacteria: physical and restriction analysis. Arch. Microbiol. 149:540-546.

27. Laemmli, U. K. 1970 . Cleavage of structural proteins during the assembly of the head of bacteriophage T4. Nature (London) 227:680-685.

28. Lalucat, J., R. Parés, and H. G. Schlegel. 1982. Pseudomonas taeniospiralis sp. nov., an R-body-containing hydrogen bacterium. Int. J. Syst. Bacteriol. 32:332-338.

29. Marmur, J. A. 1961. A procedure for the isolation of deoxyribonucleic acid from micro-organisms. J. Mol. Biol. 3:208218.

30. Marmur, J., and P. Doty. 1962. Determination of the base composition of deoxyribonucleic acid from its thermal denaturation temperature. J. Mol. Biol. 5:109--118.

31. Mayberry, W. R. 1981. Dihydroxy and monohydroxy fatty acids in Legionella pneumophila. J. Bacteriol. 147:373-381.

32. Niklewski, B. 1910. Über die Wasserstoffoxydation durch Mikroorganismen. Jahrb. Wiss. Bot. 48:113-142.

33. Nozhevnikova, A. N., and G. A. Zavarzin. 1974. On the taxonomy of CO-oxidizing Gram-negative bacteria. Izv. Akad. Nauk SSSR Ser. Biol. 3:436-440

34. Orla-Jensen, S. 1909. Die Hauptlinien des natürlichen Bakteriensystems. Centralbl. Bakteriol. Parasitenkd. Infektionskr. Abt. 2 22:305-346.

35. Oyaizu, H., and K. Komagata. 1983. Grouping of Pseudomonas species on the basis of cellular fatty acid composition and the quinone system with special reference to the existence of 3-hydroxy fatty acids. J. Gen. Appl. Microbiol. 29:17-40.

36. Palleroni, N. J. 1984. Genus I. Pseudomonas Migula 1894, p. 141-199. In N. R. Krieg and J. G. Holt (ed.), Bergey's manual of systematic bacteriology, vol. 1. The Williams \& Wilkins Co., Baltimore.

37. Palleroni, N. J., R. Kunisawa, R. Contopoulou, and M. Doudoroff. 1973. Nucleic acid homologies in the genus Pseudomonas. Int. J. Syst. Bacteriol. 23:333-339.

38. Pot, B., M. Gillis, B. Hoste, A. Van De Velde, F. Bekaert, K. Kersters, and J. De Ley. 1989. Intra- and intergeneric relationships of the genus Oceanospirillum. Int. J. Syst. Bacteriol. 39:23-34

39. Rossau, R., K. Kersters, E. Falsen, E. Jantzen, P. Segers, A. Union, L. Nehls, and J. De Ley. 1987. Oligella, a new genus including Oligella urethralis comb. nov. (formerly Moraxella urethralis) and Oligella ureolytica sp. nov. (formerly CDC group IVe): relationship to Taylorella equigenitalis and related taxa. Int. J. Syst. Bacteriol. 37:198-210.

40. Sneath, P. H. A., and R. R. Sokal. 1973. Numerical taxonomy. The principles and practice of numerical classification. W. $\mathbf{H}$ Freeman and Co., San Francisco.

41. Stackebrandt, E., R. G. E. Murray, and H. G. Trüper. 1988. Proteobacteria classis nov., a name for the phylogenetic taxon that includes the "purple bacteria and their relatives." Int. J. Syst. Bacteriol. 38:321-325.

42. Tamaoka, J., D.-M. Ha, and K. Komagata. 1987. Reclassification of Pseudomonas acidovorans den Dooren de Jong 1926 and Pseudomonas testosteroni Marcus and Talalay 1956 as Comamonas acidovorans comb. nov. and Comamonas testosteron comb. nov., with an emended description of the genus Comamonas. Int. J. Syst. Bacteriol. 37:52-59.

43. Van Landschoot, A., and J. De Ley. 1983. Intra- and intergeneric similarities of the rRNA cistrons of Aiteromonas, Marinomonas (gen. nov.) and some other Gram-negative bacteria. J. Gen. Microbiol. 129:3057-3074.

44. Willems, A., M. Gillis, K. Kersters, L. Van den Broecke, and J. De Ley. 1987. Transfer of Xanthomonas ampelina Panagopoulos 1969 to a new genus, Xylophilus gen. nov., as Xylophilus ampelinus (Panagopoulos 1969) comb. nov. Int. J. Syst. Bacteriol. 37:422-430. 
45. Wishart, D. 1978. Clustan user manual, 3rd ed. Program Library Unit, Edinburgh University, Edinburgh, Scotland.

46. Woese, C. R., P. Blanz, and C. Hahn. 1984. What isn't a pseudomonad: the importance of nomenclature in bacterial classification. Syst. Appl. Microbiol. 5:179-195.

47. Wold, S., C. Albano, W. J. Dunn III, U. Edlund, K. Esbensen, P.
Geladi, S. Hellberg, S. Johanson, W. Lindberg, and M. Sjöström. 1984. Multivariate data analyses in chemistry, p. 17-95. In B. R. Kowalsky (ed.), Chemometrics, mathematics and statistics in chemistry. V, Dordrecht, The Netherlands.

48. Zavarzin, G. A., and A. N. Nozhevnikova. 1977. Aerobic carboxydobacteria. Microb. Ecol. 3:305-326. 